\title{
Genetic associations in type I interferon related pathways with autoimmunity
}

\author{
Angélica M Delgado-Vega', Marta E Alarcón-Riquelme ${ }^{1,2,3}$ and Sergey V Kozyrev*1
}

\begin{abstract}
Type I interferons play an outstanding role in innate and adaptive immunity by enhancing functions of dendritic cells, inducing differentiation of monocytes, promoting immunoglobulin class switching in B cells and stimulating effector functions of T cells. The increased production of IFNa/ $\beta$ by plasmacytoid dendritic cells could be responsible for not only efficient antiviral defence, but it also may be a pathological factor in the development of various autoimmune disorders. The first evidence of a genetic link between type I interferons and autoimmune diseases was the observation that elevated IFNa activity is frequently detected in the sera of patients with systemic lupus erythematosus, and that this trait shows high heritability and familial aggregation in their first-degree healthy relatives. To date, a number of genes involved in interferon signalling have been associated with various autoimmune diseases. Patients with systemic lupus erythematosus, Sjögren's syndrome, dermatomyositis, psoriasis, and a fraction of patients with rheumatoid arthritis display a specific expression pattern of interferon-dependent genes in their leukocytes, termed the interferon signature. Here, in an attempt to understand the role of type I interferons in the pathogenesis of autoimmunity, we review the recent advances in the genetics of autoimmune diseases focusing on the association of genes involved in type I interferon pathways.
\end{abstract}

\section{Introduction}

Type I interferons comprise a large group of structurally similar cytokines that includes 13 subtypes of IFN $\alpha$ and unique IFN $\beta$, IFNe, IFNK and IFN $\omega$ in humans, which

\footnotetext{
*Correspondence: sergey.kozyrev@genpat.uu.se

'Department of Genetics and Pathology, Rudbeck Laboratory, Uppsala University, Dag Hammarskjölds väg 20, 75185 Uppsala, Sweden

Full list of author information is available at the end of the article
}

exert similar but not identical effects due to their different binding affinities to a common cognate receptor $[1,2]$. Genes coding for the type I interferons are clustered on human chromosome 9p22 and apparently originated from a duplication of a single gene [3]. Both the number of genes and their intronless structure point to the vital role of interferons in host defence against viruses. During a viral infection, type I interferons activate innate immune responses and exert anti-proliferative and cytotoxic effects on cells. Type I interferons also induce survival, maturation and activation of different subsets of dendritic cells, thereby enhancing their antigen-presenting abilities. Activated dendritic cells upregulate expression of human leucocyte antigen and other co-stimulatory molecules, such as CD40, CD80, CD83 and CD86 [4-6], and initiate the production of cytokines such as TNF $\alpha$, IL-6, IL-10, IL-12, IL-15, IL-18, IL-23 [7-10], B-cell activating factor $[11,12]$, and the chemokines CCL3, CCL4, CCL5, and CXCL10 [13-17], which in turn exert co-stimulatory effects on all other immune cells.

Type I interferons link together both innate and adaptive immune systems. Their effects in adaptive immunity are mediated through activated dendritic cells and also by direct binding to interferon receptors on B cells, $\mathrm{T}$ cells, neutrophils and natural killer (NK) cells. They promote immunoglobulin class switching and antibody production in B cells, promote T-cell effector activity and promote synthesis of IFNY by T cells and NK cells, and they protect both $\mathrm{B}$ cells and $\mathrm{T}$ cells from apoptosis [18-32].

Type I interferons can also promote pathologic autoimmunity; IFN $\alpha$ is able to break self-tolerance by activating antigen-presenting cells after uptake of self material [33]. The first genetic link between type I interferons and autoimmune diseases was provided by the observation of an elevated IFN $\alpha$ level in the sera of patients with systemic lupus erythematosus (SLE), and the familial aggregation of this trait in healthy relatives [34-37]. This observation suggested that the alteration of the interferon pathway is a primary event in SLE pathogenesis, rather than a consequence of the disease phenotype. The levels of IFN $\alpha$ activity in patients with SLE are positively correlated with both clinical and serological 
markers of disease activity [34,35,37,38]. Increased levels of IFN $\alpha$ were also observed in patients with rheumatoid arthritis (RA), scleroderma and primary Sjögren's syndrome (pSS) [34]. Moreover, about $20 \%$ of patients with long-term treatment of haematological malignancies and viral hepatitis infections with recombinant IFN $\alpha$ develop lupus or other autoimmune diseases, such as type 1 diabetes, psoriasis, inflammatory arthritis and pSS, or show symptoms resembling autoimmune diseases $[39,40]$. These results together further substantiate the involvement of IFN $\alpha$ in the development of various autoimmune disorders.

SLE patients display another important feature of an active interferon-mediated signalling: an overexpression of genes regulated by type I interferon, termed the interferon signature, which is more prominent in patients with severe disease [41]. In agreement with the idea of a shared genetic basis of autoimmune diseases [42], the interferon signature has also been demonstrated for pSS, dermatomyositis, psoriasis and some RA patients [43].

In the present review we will give a brief overview of the type I interferon signalling, with the main focus on the genetic linkage between type I interferon-mediated pathways and autoimmune diseases. True functional variants for the majority of associated genes have not yet been found, and for that reason the biology behind them is largely unknown. Owing to the space constraints, we shall examine in detail only a few genes with either strong or consistent evidence of association with autoimmune diseases for which functional variants have been described or, at least, proposed. A more complete list of associated genes involved in interferon-related pathways is presented in Table 1.

\section{Genetic linkages to the pathways inducing production of type I interferons}

Although all nucleated cells can produce type I interferons in response to viral infections, there is a group of professional cells producing extremely high amounts: the plasmacytoid dendritic cells (pDCs) [44,45]. The bulk yield of interferons may reach 3 to $10 \mathrm{pg} /$ cell, which is estimated to be about 1,000 times more than in cells of any other type. The ability of cells to sense infections is linked to the special sensors localized on the membrane and in the cytosol (Figure 1). The first group consists of the Toll-like receptors (TLRs), of which TLR3, TLR4, TLR7/8 and TLR9 transmit the signal resulting in the induction of interferon genes after ligation with dsRNA, bacterial lipopolysaccharides, single-stranded RNA and unmethylated CpG-rich DNA, respectively [46]. Unlike cells of other types, pDCs express only TLR7 and TLR9, giving these two receptors a paramount importance in type I interferon production [47-51]. Another group of ubiquitous sensors, the RNA helicases retinoic acid-inducible gene 1 and melanoma differentiation-associated gene 5 , reside in the cytoplasm and recognize dsRNA and viral replicating intermediates $[52,53]$. The presence of viral RNA in the cytoplasm may activate the ultimate weapons of the antiviral defence dsRNA-dependent serine-threonine kinase [54] and $2^{\prime}, 5^{\prime}$-oligoadenylate synthetase [55] - resulting in complete stalling of the cellular transcription and translation in the infected cell and, eventually, apoptosis. It was shown recently that cytoplasmic dsDNA could be recognized by two cytosolic dsDNA sensors: DNA-dependent activator of interferon regulatory factors (IRFs), and absent in melanoma 2 - both signal through TBK1 and IRF3, and induce genes for IFN $\beta$ and proinflammatory cytokines [56]. The binding of absent in melanoma 2 to dsDNA leads to activation of caspase 1 and caspase 3, which cleaves and releases IL-1 $\beta$ and IL-18 [57-61].

Interestingly, autophagy - an autonomous process of re-utilization of cellular organelles - has been also implicated in the induction of innate immune responses and production of type I interferons [62]. Viral RNA could be engulfed by a forming autophagosome and, after fusing it with an endosome, could be detected by TLR7. Mouse pDCs lacking the autophagy-related 5 (yeast) (Atg5) gene showed a decreased IFN $\alpha$ response and were unable to respond to vesicular stomatitis virus infection [62].

It is important to note that the activation of a particular pathway depends upon the cell type, the nature of the pathogen and the cytokines present in the milieu. All of these factors determine the pattern of induced genes, which could vary from the induction of IFN $\alpha / \beta$ genes in pDCs in response to certain viral infections to the induction of genes for other proinflammatory cytokines in another cell type.

Transcription factors at the knots of the signalling cascades IRF5 belongs to the family of IRFs and plays an essential role in many aspects of cellular responses to interferons, including antiviral defence, cell growth regulation and apoptosis [63-67]. The IRF5 gene was associated first with SLE $[68,69]$, and since then its association has been established with many other autoimmune diseases, including RA [70], Sjögren's syndrome [71], inflammatory bowel disease [72], and multiple sclerosis [73]. The genetics of IRF5 is very well studied to date, and finds support in the functional analysis of the associated causative variants. Several functional polymorphisms are believed to play a major role in determining the gene function in the pathogenesis, including: the promoter CGGGG insertion/deletion, which strengthens the binding site for the Sp1 transcription factor and thus affects the expression of the gene [74]; the SNP rs2004640, which creates an alternative $5^{\prime}$-donor splice site leading to the splicing of the alternative $5^{\prime}$-UTR exon $1 \mathrm{~B}$; the in-frame 
Table 1. Genetic associations involving molecules of the type I interferon pathway

\begin{tabular}{|c|c|c|c|c|c|}
\hline Chromosome & Gene & $\begin{array}{l}\text { Associated } \\
\text { polymorphisms }\end{array}$ & Disease/trait & $\begin{array}{l}\text { Functional effect } \\
\text { (if demonstrated) }\end{array}$ & References \\
\hline \multicolumn{6}{|c|}{ Genes with strong evidence of association and/or good replication studies } \\
\hline $1 \mathrm{q} 21-24$ & FCGR2A & rs1801274 (R131H) & SLE, PAPS & $\begin{array}{l}\text { R131 has lower affinity to } \operatorname{lgG}_{2} \text {, which may affect the } \\
\text { clearance of immune complexes }\end{array}$ & {$[85,105,106]$} \\
\hline \multirow[t]{2}{*}{$2 q 24.3$} & IFIH1 (MDA-5) & $\begin{array}{l}\text { rs } 1990760(\text { T946A), } \\
\text { rs37477517 (ㅈ43H) }\end{array}$ & $\begin{array}{l}\text { T1D, RA, } \\
M S, G D\end{array}$ & & {$[183-186]$} \\
\hline & & $\begin{array}{l}\text { rs35337543 }(\underline{G}>C) \\
\text { rs35667974 }(\underline{19} 23 V) \\
\text { rs35744605 } \\
\text { rs357327X) }\end{array}$ & T1D & $\begin{array}{l}\text { E627X and } 1923 \mathrm{~V} \text { are loss of function mutations. } \\
\text { E627X results in deletion of the C-terminal region } \\
\text { necessary for dsRNA binding activity. } 1923 \mathrm{~V} \text { alters a } \\
\text { conserved residue, which might impair the signalling }\end{array}$ & {$[10,187]$} \\
\hline $7 q 32$ & IRF5 & $\begin{array}{l}\text { CGGGG promoter insertion/ } \\
\text { deletion, rs2004640, exon } 6 \\
\text { insertion/deletion rs10954213 }\end{array}$ & $\begin{array}{l}\text { RA, T1D, SLE, } \\
\text { IBD, pSS }\end{array}$ & $\begin{array}{l}\text { CGGGG and rs } 10954213 \text { risk alleles enhance } \\
\text { expression levels of IRF5. SNP rs } 2004640 \text { and exon } 6 \\
\text { insertion/deletion determine alternative splice isoforms }\end{array}$ & $\begin{array}{r}{[68,70,72,74,} \\
75,78,188]\end{array}$ \\
\hline $2 q 32.2$ & STAT4 & $\begin{array}{l}\text { rs } 7574865, \text { rs } 7568275 \\
\text { rs3821236, rs } 10168266\end{array}$ & $\begin{array}{l}\text { RA, SLE, pSS, } \\
\text { psoriasis, PAPS }\end{array}$ & $\begin{array}{l}\text { Risk haplotype associated with high levels of expression } \\
\text { and greater sensitivity to IFNa }\end{array}$ & $\begin{array}{c}\quad[144,146- \\
150,164,169, \\
189,190]\end{array}$ \\
\hline $9 p 13.2$ & TYK2 & $\begin{array}{l}\text { rs } 2304256, \text { rs } 12720270, \\
\text { rs } 34536443\end{array}$ & SLE, MS & $\begin{array}{l}\text { rs } 12720270 \text { located in a intron/exon boundary might } \\
\text { be involved in alternative splicing }\end{array}$ & $\begin{array}{l}{[69,141-143,} \\
149]\end{array}$ \\
\hline $8 p 23-p 22$ & $B L K$ & rs13277113, rs2736340 & SLE, PAPS & $\begin{array}{l}\text { Promoter SNPs associated with reduced expression } \\
\text { of } B L K\end{array}$ & {$[145,149,169]$} \\
\hline $4 q 24$ & BANK1 & $\begin{array}{l}\text { rs } 10516487(\mathrm{R} 61 \mathrm{H}), \text { rs17266594, } \\
\text { rs3733197 (A383T) }\end{array}$ & SLE, RA & $\begin{array}{l}\text { rs } 17266594 \text { determines the transcription ratio } \\
\text { between the full-length and delta } 2 \text { isoforms }\end{array}$ & {$[149,166,171-173]$} \\
\hline \multicolumn{6}{|l|}{ Good evidence } \\
\hline 1q21-24 & FCGR3B & $\begin{array}{l}\mathrm{NA} 1 / \mathrm{NA} 2 \text {, } \mathrm{CNV} \text { of the } \\
\text { whole gene }\end{array}$ & SLE, mPA, WG & $\begin{array}{l}\text { NA1-homozygous has stronger FcyR-mediated } \\
\text { phagocytic response. Increased risk for SLE with } \\
<2 \text { gene copies }\end{array}$ & {$[107]$} \\
\hline $4 q 21-q 25$ & SPP1 & $\begin{array}{l}\text { rs1126616, rs1126772, } \\
\text { rs9138, rs7687316 }\end{array}$ & & $\begin{array}{l}\text { 3'-UTR polymorphisms associated with high } \\
\text { amounts of ostepontin and IFNa in sera of } \\
\text { patients with SLE. Evidence of rs9138-gender } \\
\text { interaction }\end{array}$ & {$[130,131,136,137]$} \\
\hline \multirow[t]{2}{*}{$5 q 32-q 33.1$} & TNIP1 & rs10036748, rs7708392 & SLE & $\begin{array}{l}\text { No functional polymorphism yet identified. TNIP1 } \\
\text { is the A20-binding inhibitor of NF-KB activation and } \\
\text { together with A-20 serves as brake for interferon } \\
\text { production induced via TLR }\end{array}$ & {$[86,136,191]$} \\
\hline & & rs17728338 & Psoriasis & & \\
\hline $16 p 13.3$ & DNASEI & $\begin{array}{l}\text { V89M, K5X, 46_72 deletion, } \\
\text { rs179982-rs1030874-rs1059857 } \\
\text { haplotype,. }\end{array}$ & SLE, AITD & $\begin{array}{l}\text { V89M and K5X are associated with lower enzymatic } \\
\text { activity. Haplotype rs179982-rs 1030874-rs1059857 } \\
\text { defines isoforms of DNasel }\end{array}$ & {$[179,192-194]$} \\
\hline $3 p 21.31$ & $\begin{array}{l}\text { TREX1 } \\
\text { (DNASEIII) }\end{array}$ & $\begin{array}{l}\text { R114H, } 158 \mathrm{~V}, \mathrm{P} 212 \mathrm{fs}, \mathrm{G} 227 \mathrm{~S} \\
\text { R240S, A247, P272fs, P290L, } \\
\text { Y305C, G306A }\end{array}$ & SLE, pSS & $\begin{array}{l}\text { R114H associated with decreased exonuclease } \\
\text { activity. Frameshift mutations D272fs and P212fs alter } \\
\text { subcellular localization of the protein }\end{array}$ & {$[180,181]$} \\
\hline \multicolumn{6}{|c|}{ Good evidence but more replication studies are required } \\
\hline $2 p 13-p 12$ & REL & rs13031237, rs13017599 & RA & & [93] \\
\hline $3 q 13.11$ & $C B L B$ & F328L & T1D & & {$[195]$} \\
\hline $1 \mathrm{q} 21-24$ & FCGR3A & rs396991, V176E & Lupus nephritis & & {$[105]$} \\
\hline $1 \mathrm{q} 21-24$ & FCGR2B & $1232 \mathrm{~T}$ & SLE & & {$[105]$} \\
\hline $8 q 13$ & $L Y N$ & rs6983130 & SLE & & {$[85,176]$} \\
\hline $5 q 31.1$ & IRF1 & rs2070721 & $M S, J A$ & & {$[161,196]$} \\
\hline $2 q .36$ & IRST & rs1801278, G972므 & $\mathrm{T} 1 \mathrm{D}$ & & [197] \\
\hline $16 q 24.1$ & IRF8 & rs17445836 & MS & & {$[90]$} \\
\hline $2 q 32.2$ & STAT1 & rs2066802, rs1547550 & MS & & [161] \\
\hline $11 \mathrm{q} 24.2$ & TIRAP & rs8177374, S180L & SLE, IBD & & {$[198,199]$} \\
\hline
\end{tabular}


Table 1. Continued

\begin{tabular}{|c|c|c|c|c|c|}
\hline Chromosome & Gene & $\begin{array}{l}\text { Associated } \\
\text { polymorphisms }\end{array}$ & Disease/trait & $\begin{array}{l}\text { Functional effect } \\
\text { (if demonstrated) }\end{array}$ & References \\
\hline \multicolumn{6}{|c|}{ Good evidence but more replication studies are required } \\
\hline $6 \mathrm{q} 21$ & ATG5 & rs6568431 & SLE & & [85] \\
\hline Xq28 & IRAK1 & $\begin{array}{l}\text { rs2239673-rs763737- } \\
\text { rs5945174-rs7061789 GGGG } \\
\text { haplotype }\end{array}$ & SLE & & [200] \\
\hline \multicolumn{6}{|c|}{ Inconsistent replication } \\
\hline $9 q 32-q 33$ & TLR4 & rs4986790 (G299D) & RA, GCA & & {$[201,202]$} \\
\hline $9 p 22$ & \multicolumn{2}{|l|}{ IFNA gene cluster } & SLE, MS & & {$[203,204]$} \\
\hline $21 q 22.11$ & IFNAR cluster & IFNAR1:18417, IFNAR2: 11876 & MS & & [205] \\
\hline $4 q 24$ & NFKB1 & $\begin{array}{l}\text {-94 ATTG insertion/deletion, } \\
\text { CA microsatellite }\end{array}$ & T1D, UC, GD & & {$[99,101]$} \\
\hline $3 p 21.3$ & TLR9 & $+1174 A>G$ & SLE & & [206] \\
\hline $17 q 21$ & STAT3 & rs744166, rs12948909 & CD & & [162] \\
\hline 19q13.3-q13.4 & IRF3 & rs2304204, rs2304206 & SLE & & [88] \\
\hline
\end{tabular}

Alleles associated with increased risk to develop the disease are underlined (alleles over-represented in patients). SLE, systemic lupus erythematosus; PAPS, primary anti-phospholipid syndrome; T1D, type 1 diabetes; RA, rheumatoid arthritis; MS, multiple sclerosis; GD, Graves' disease; IBD, inflammatory bowel disease; pSS, primary Sjögren's syndrome; mPA, microscopic polyangiitis; WG, Wegener's granulomatosis; AITD, autoimmune thyroid diseases; JIA, juvenile idiopathic arthritis; GCA, giantcell arteritis; UC, ulcerative colitis; $C D$, Crohn's disease.

insertion/deletion of the repetitive sequence in exon 6, which makes two families of the alternative IRF5 transcripts [75] (the exon 6 insertion/deletion is located in the putative PEST domain of the protein, but its function at present remains unknown); and, finally, the SNP rs10954213, which alters the polyadenylation signal. The presence of the $G$ allele results in a longer 3'-UTR with two AU-rich elements rendering the transcript for rapid degradation, while the A allele generates mRNA with a short and stable $3^{\prime}$-UTR [76]. It has been shown that only the promoter insertion/deletion and the poly(A) SNP alter the gene expression levels [77]. The level of the alternative transcripts caused by the T allele of rs2004640 is very low, and it encodes for essentially the same protein isoforms as the transcripts with the major exon $1 \mathrm{~A}$.

A high-risk IRF5 haplotype has been defined and is predicted to give rise to transcripts expressing exon $1 \mathrm{~B}$ isoforms (rs2004640-T), to carry the exon 6 insertion, and to be overexpressed because of the poly(A) variant (rs10954213-A) [78]. The fourth variant is rs20710197(C), or its proxy rs10488631, and is an excellent predictor or tag of the risk haplotype in Caucasians and Hispanics [68,77-80]. Niewold and colleagues demonstrated that this well-defined SLE risk haplotype is associated with higher serum IFN $\alpha$ activity in patients with SLE [79]. Moreover, the differential effect of the IRF5 genotype on serum IFN $\alpha$ activity is more pronounced in SLE patients positive for either anti-RNA-binding proteins (anti-RNP) or anti-dsDNA autoantibodies [79]. This effect suggests the possibility of a tight link between autoantibodies and IRF5; that is, autoantibodies containing residual nucleic acids may enhance TLR-mediated signalling in individuals with a given risk genotype, and hence high expression of IRF5, and may predispose them to a greater production of IFN $\alpha$.

The strong genetic link of IRF5 with various autoimmune diseases across many populations may be due to the place IRF5 has in the signalling cascades. It lies downstream in the signalling path of many different receptors (TLR4, TLR7/8, TLR9), and thus can respond to diverse pathogens [81-83]. Furthermore, the gene is expressed in pDCs, monocytes and B cells, and its enhanced function may cause overexpression of IFN $\alpha / \beta$ and the proinflammatory cytokines TNF $\alpha$, IL-6 and IL-12 in these cells [83]. Many other genes, including the transcription factors signal transducer and activator of transcription (STAT) 1 and STAT3, which mediate the interferon-signalling pathway, are also regulated by IRF5. Overexpression of IRF5 may lead to accelerated apoptosis, contributing to the increased burden on the immune clearance system [65,75]. The enhanced function of the IRF5 gene caused by the highrisk allelic variants may therefore lead to systemic effects of the immune system.

In this regard it is interesting to mention that the frequency of the IRF5 risk haplotype among healthy Mexicans is higher compared with that among Europeans (20\% vs. 9\%) and is even higher in Mazateco Mexican Indians (31\%) [80]. As for the lupus patients, the difference is even more striking - with $20 \%$ of the homozygous haplotype in Mexican SLE patients as compared with 3.3\% in European SLE patients. It is tempting to speculate that this phenomenon originated from the positive 


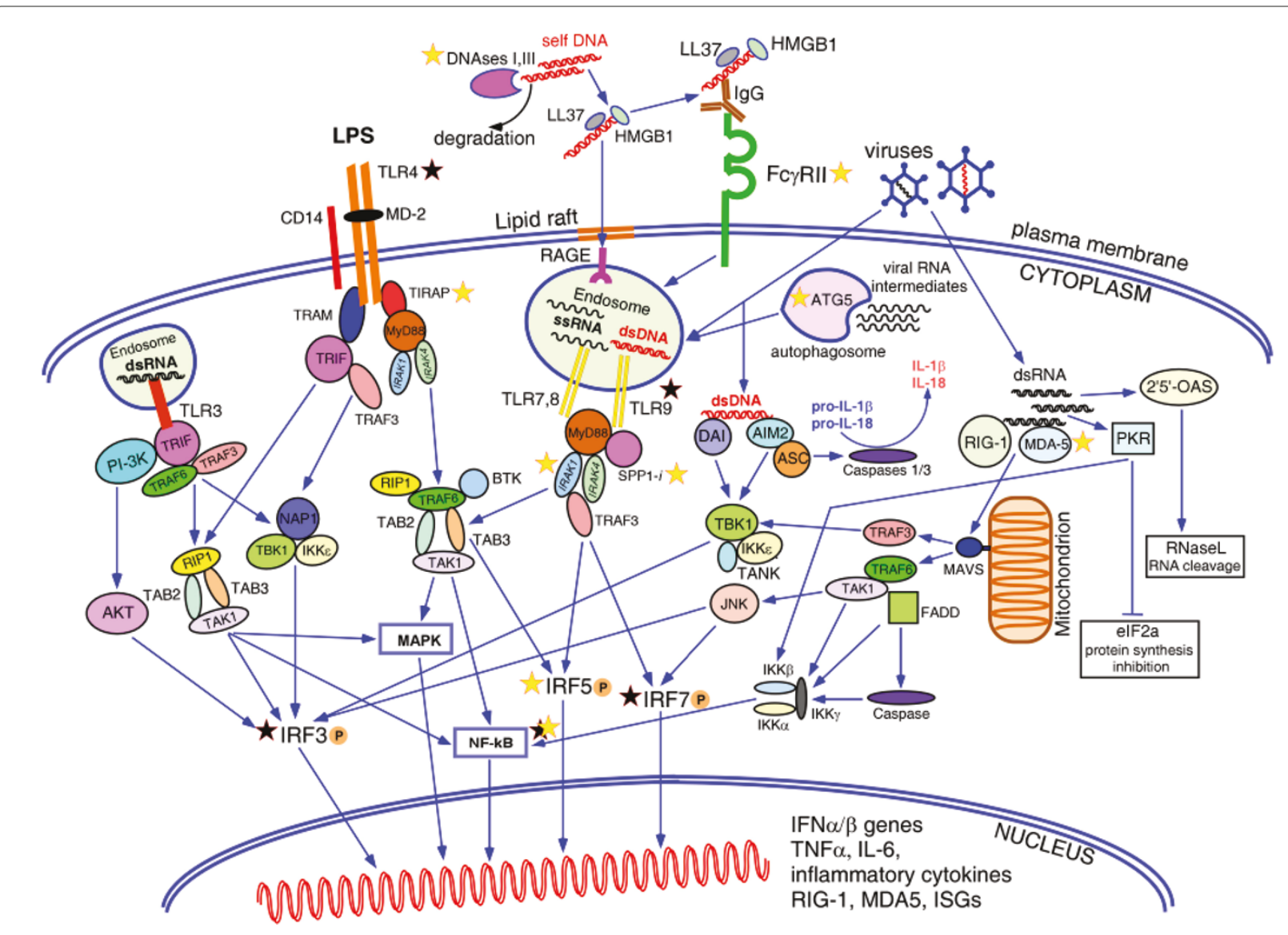

Figure 1. Pathways leading to the type I interferon production. Among the family of Toll-like receptors (TLRs), TLR3, TLR4, TLR7/8 and TLR9 are known to induce production of type I interferons in various cells. Surface TLR4 recognizes lipopolysaccharides (LPS) from bacterial cell walls and trasmit the signal downstream via MyD88-dependent or MyD88-independent pathways resulting in phosphorylation, dimerization and nuclear translocation of IRF5 and IRF3, and activation of NF-KB and mitogen-activated protein kinase (MAPK) pathways. Intracellular TLR3, TLR7/8 and TLR9 residing in the endosomes are activated by viral double-stranded (ds)RNA, single-stranded RNA and unmethylated dsDNA, respectively. TLR3 signals via adaptor TRIF and activates IRF3, NF-KB and MAPK pathways. TLR7/8 and TLR9 transmit the signal via the adaptor molecule MyD88. The intracellular form of osteopontin 1 (SPP1) binds to MyD88 upon ligation of TLR9 with unmethylated CpG oligonucleotides and promotes induction of IFNa genes in mouse plasmacytoid dendritic cells (pDCs). TLR7 and TLR9 are the only receptors expressed in pDCs, while other cells contain other TLRs as well. Detection of nucleic acids by TLRs in intracellular endosomes prevents immune responses to the host self-DNA. Normally, nucleic acids released by dying necrotic or apoptotic cells undergoing rapid degradation by nucleases, DNasel and DNaselll (TREX1), while bacterial or viral nucleic acids are protected by the cell wall or viral capsid and could be detected by TLRs only after penetrating the cell. Breach of tolerance to selfDNA and activation of pDCs could happen if self-DNA remains undegraded due to defective function of the nucleases and meet endosomal TLR9. Cationic antimicrobial peptide LL37 and high-mobility group box 1 protein (HMGB1) released by damaged or infected cells, mainly keratinocytes and neutrophils, bind DNA making it resistant to degradation and facilitate endocytosis of DNA through the lipid rafts and receptor for advanced glycation end-products (RAGE), delivering it to TLR9. DNA/DNA-protein aggregates could be recognized by anti-DNA/anti-RNA-binding proteins (anti-RNP) antibodies produced by the autoreactive B cells. Binding of these immune complexes to the low-affinity Fcy receptors II leads to their internalization and translocation to the endosomes containing TLR9. Viral DNAs residing in the cytoplasm could be detected by two cytoplasmic DNA sensors, DNA-dependent activator of interferon regulatory factors (DAI) and absent in melanoma 2 (AIM2), which trigger induction of type I interferon genes through TBK1-mediated and IRF3-mediated signalling. AIM2 also activates caspases 1 and 3 by recruiting adaptor ASC (apoptosisassociated speck-like protein containing a CARD) and forming an inflammasome that promotes release of IL-1 $\beta$ and IL-18. Two RNA helicases, retinoic acid-inducible gene 1 (RIG-1) and melanoma differentiation-associated gene 5 (MDA-5), detect viral RNAs in the cytoplasm. Activated RIG-1 and MDA- 5 interact with adaptor protein MAVS anchored by its C-terminal domain to a mitochondrion. This interaction triggers signalling through TRAF3 and TRAF6 adaptors and results in activation of IRF3, IRF7 and NF-KB pathway. Autophagosomes can engulf the replicating viral RNAs and, after fusion with endosomes, present it to the TLR7/8. Viral RNAs can induce a common antiviral defence mechanism aimed at blocking viral replication through total inhibition of cellular transcription and translation. Thus, dsRNAs activate 2',5'-oligoadenylate synthase (OAS) producing 2',5'-oligoadenylates, which in turn activate the latent nuclease RNase L, resulting in the degradation of all cytoplasmic RNAs. Another pathway targets protein synthesis machinery by protein kinase dsRNA-dependent serine-threonine kinase (PKR), which inactivates the alpha subunit of initiation factor elF2, resulting in rapid inhibition of protein translation. The latter two pathways may induce apoptosis of the infected cell. Yellow stars, genes with strong evidence for association with autoimmune diseases; black stars, genes with inconsistent association. ISG, interferon stimulated genes; PI3K, phosphoinositide 3-kinase. 
selective pressure on Mexican Indians carrying risk alleles, and hence high expression of IRF5 and interferons, which gave them survival advantages against certain viral infections brought from the Old World. At the same time, the side effect of this survival might be leading to a more severe SLE in Mexican patients, characterized by the earlier onset and frequent renal and other organ damage [84].

Remarkably, neither IRF3 nor IRF7 seem to be reliably associated with autoimmunity. Although a SNP (rs4963128) in PHRF1 (previously known as KIAA1542) has been convincingly associated with SLE $[85,86]$, and this association is believed to be due to linkage disequilibrium (LD) with $I R F 7$, no study has yet directly tested $I R F 7$. The PHRF1 and IRF7 genes are localized on chromosome $11 \mathrm{p} 15$ in a tail-to-tail mode. The haplotype structure of the HapMap-CEU population (data Release 27) [87] shows that both loci are located within the same haplotype block together with the mucin-like protocadherin $M U P C D H$. The associated PHRF1 variant is $23 \mathrm{~kb}$ downstream of IRF7 and is in rather moderate LD with two SNPs in IRF7: rs12805435 $\left(r^{2}=0.475\right)$ and rs10902178 $\left(r^{2}=0.475\right)$. Thus, even though IRF7 is the most plausible candidate in this region given its function in IFN $\alpha$ production, its role as a susceptibility gene for SLE remains to be verified.

A promoter polymorphism in the IRF3 gene conferring higher expression of IRF3 was associated with SLE in one Japanese study [88]; however, the association was not corroborated on a larger set of Spanish patients [89]. Of note, IRF3 is constitutively expressed at high levels in all cells, while low levels of IRF7 are present in cells of lymphoid origin. This contrasts to an even more restricted pattern of expression of the IRF5 gene, as mentioned above.

The SNP rs17445836 located $61 \mathrm{~kb}$ downstream of the IRF8 gene has been recently associated with multiple sclerosis [90]. Although the authors concluded that the most likely susceptibility gene was $I R F 8$, the block where the SNP is located is separated from IRF8 by three recombination hot spots [90]. Interestingly, the presence of the risk allele $\mathrm{G}$ of rs 17445836 was positively correlated with expression levels of the IRF7 and IFIH1 genes, but not with $I R F 8$ itself or interferon genes.

The transcription factor NF- $\mathrm{kB}$ is a central regulator of immune responses and inflammation, and is present virtually in all cell types. It is composed of homodimers or heterodimers formed by the members of the NF- $\mathrm{kB}$ family, which include RelA (p65), RelB, c-Rel, NF-kB1 (p50) and NF-kB2 (p52) [91]. Single and double knockout mouse models for these genes display survival and phenotypic differences, suggesting that, despite some overlapping functions, they all have unique roles in the immune system (reviewed in [92]). Recently, the gene coding for $\mathrm{c}-\operatorname{Rel}(R E L)$ was identified as a susceptibility locus for RA [93]. c-Rel expression is restricted to haematopoietic cells and lymphocytes, and mainly to $\mathrm{T}$ cells and B cells. In contrast, RelA, NF- $\mathrm{kB} 1$ and NF- $\mathrm{kB} 2$ are widely expressed in various cell types and constitute the major classic NF- $\mathrm{kB}$ factor, residing in its inactive form in the cytoplasm. Stimulation of cells activates $\mathrm{NF}-\mathrm{kB}$, which translocates into the nucleus and induces the expression of a great number of genes. Interestingly, constitutively active nuclear heterodimer p50/c-Rel is found in mature $\mathrm{B}$ cells also co-expressing the cytoplasmic heterodimer $\mathrm{p} 50 / \mathrm{p} 65$, suggesting a specific function for c-Rel in B-cell stimulation [94]. Mice deficient for c-Rel develop normally and display only unresponsiveness of B cells and $\mathrm{T}$ cells to certain mitogenic stimuli [95]. B cells lacking c-Rel show increased sensitivity to B-cell receptor-mediated apoptotic signals [96]. c-Rel is indispensable for expression of IL-12 and IL-23 subunits in mouse dendritic cells $[97,98]$.

With exception for one more member of the family, $\mathrm{NF}-\kappa \mathrm{B}_{1}$ - which has been inconsistently associated with genetic susceptibility to some of the autoimmune diseases [99-101] - no other factors were found to be linked with autoimmunity. Remarkably, NF- $\mathrm{KB}_{1}$ knockout mice - unlike knockout mice for RelA, RelB, or NF- $\mathrm{kB}_{2}-$ have only minor defects in lymphocyte activation, and particularly in B-cell responses [102].

\section{Genes involved in clearance of immune complexes - Fc gamma receptors}

SLE patients display an increased rate of apoptosis of peripheral mononuclear cells and decreased clearance of the circulating immune complexes (ICs), which together may lead to the accumulation of high titres of ICs and cause organ damage [103,104]. The Fc gamma receptors $(\mathrm{Fc} \gamma \mathrm{R})$ are low-affinity receptors for the Fc portion of IgG and play a critical role in the clearance of ICs. Several polymorphisms for FcyRIIa, FcyRIIb, FcyRIIIa and FcyRIIIb genes located in a tight cluster on chromosome 1q23 have been associated with SLE, lupus nephritis and primary anti-phospholipid syndrome [85,105-107]. The most consistent association, replicated in various populations of diverse ethnic groups, is the missense variation of FCGR2A (Arg131His) located in the ligand binding domain of the receptor [106]. Arginine coded by the susceptibility allele significantly reduces the affinity of binding to circulating $\operatorname{IgG}_{2}$. This, in turn, results in impaired FcyR-mediated phagocytosis and poor clearance of ICs.

Receptor ligation leads to the activation and maturation of dendritic cells and enhances their ability to stimulate $\mathrm{T}$ cells via cross-presentation of antigens and enhanced secretion of inflammatory cytokines. Interestingly, pDCs express Fc $\gamma$ RIIa containing the activation ITAM domain, 
but not Fc $\gamma$ RIIb with the inhibitory ITIM domain [108]. It was shown also that ligation of Fc $\gamma$ RIIa triggers IFN $\alpha$ production by pDCs [108]. In this regard, it is unclear how to reconcile the stimulatory function of the receptor on the interferon genes and the association with the risk allele that impairs this function. It might be that the primary effect is cell-type specific and unrelated to interferon production, and is rather the result of impaired internalization of immune complexes. Since FcyRIIa is present also on the surface of neutrophils, monocytes, macrophages, and platelets, its dysfunction on these cells could yield to the greater amount of circulating ICs. It has also been suggested that FcyRIIa might have dual ability to deliver both activating and inhibiting signals depending on the cell type and the milieu [108]. Another as yet unproven hypothesis suggests that variations in FcyRIIa, FcyRIIb and FcyRIIIa affect risk in a compound heterozygote fashion, and cause disbalance in stimulatory and inhibitory signals [109].

\section{Other genes required for type I interferon production}

A new function in the TLR9-mediated induction of IFNa genes in pDCs has been recently described for the intracellular form of murine osteopontin 1 (early T-lymphocyte activation protein 1, Eta-1, or SPP1) [110,111]. The majority of osteopontin 1 is secreted from activated $\mathrm{T}$ cells, NK cells and dendritic cells, and plays a key role in bone morphogenesis $[112,113]$. Its immune functions include activation of $\mathrm{T}$ cells, T-helper type 1 cell differentiation, and activation of $\mathrm{B}$ cells and macrophages [114-116]. TLR9 activation by CpG-rich DNA causes rapid association of intracellular osteopontin with the adaptor MyD88 and leads to the induction of interferon genes in an IRF7-dependent manner [111]. Although these data have been obtained from mouse dendritic cells, several lines of evidence suggest the existence of a similar pathway in humans. First, elevated levels of serum osteopontin were detected before and during relapses of different autoimmune diseases, including multiple sclerosis, SLE, RA and inflammatory bowel disease, in humans and their relevant mouse models [117-128]. Second, polymorphisms associated with autoimmunity and high levels of osteopontin were found in both species [119,129-133]. In mice IRF7 plays a major role in induction of IFN $/ \beta$ genes in $\mathrm{pDCs}$, while in humans IRF5 is more important than IRF7 - although both factors are able to induce type I interferons $[65,82,83$, 134,135]. Whether or not human osteopontin 1 is also able to activate IRF5 in human pDCs is unknown at present.

Interestingly, polymorphisms located in the 3 '-UTR region (rs1126616T and rs9138C) of the human SPP1 gene show much stronger association with SLE in men than in women [136,137]. The haplotype
rs1126616T-rs1126772A-rs9138C, however, is also associated with SLE in general [136]. Moreover, rs9138C is associated with high amounts of serum osteopontin and IFN $\alpha$ in men and young women [137]. Of note, gender-related differences in SPP1 expression were observed also in rats $[138,139]$. Bioinformatic analysis of the associated SNPs located in the 3'-UTR suggested that they might disrupt micro-RNA target sites, and thus affect the gene expression [136]. More detailed analysis is required, however, to verify this hypothesis. SNPs located in the $5^{\prime}$ region of the gene (rs11730582 and rs28357094) were associated with anti-RNP antibodies in AfricanAmericans, while in European-Americans and HispanicAmericans only a nonsignificant trend toward association was observed [137]. The study was suggested to be underpowered because of the much lower frequency of individuals carrying anti-RNP antibodies in these two populations.

\section{Genetic linkages to the signalling pathways induced by type I interferons}

Type I interferons bind to a common ubiquitous receptor composed of the two chains IFNA-R1 and IFNA-R2, coded by two distinct genes located on chromosome 21q22 [140]. The IFNA-R2 subunit is believed to have generally higher affinity to interferons, although it has been reported that various types and subtypes of type I interferon have different affinities and kinetics of binding to the receptor subunits, which may lead to differential downstream signalling [2]. The antiviral activity of interferons correlates with their binding affinities to IFNA-R2, while anti-proliferative activity depends rather on the affinity to IFNA-R1 [2]. Ligand binding causes receptor dimerization and phosphorylation of two associated protein tyrosine kinases, Tyk2 and Jak1, followed by direct activation of multiple redundant signalling pathways. The biological activities of interferons are context specific and depend upon the interferon subtype, the cell type (pDCs, T cells, B cells, NK cells, cytotoxic lymphocytes, other tissue-specific cells), concomitant signals such as cytokines present in the surrounding environment, and activation of other co-receptors (B-cell receptor/T-cell receptor, and so forth). Alternative splicing of IFNA-R2 produces two transmembrane isoforms differing in the cytoplasmic domains, and one soluble isoform may contribute to the differential signalling as well. Three major pathways transmit the signal from IFNA-R: the Jak/STAT, mitogen-activated protein kinase and phosphoinositide 3-kinase pathways (summarized in Figure 2). All of the pathways may overlap to some extent. Downstream signalling results in the induction of hundreds of genes necessary for antiviral defence, which together establish the specific pattern of genes - termed the interferon signature. 


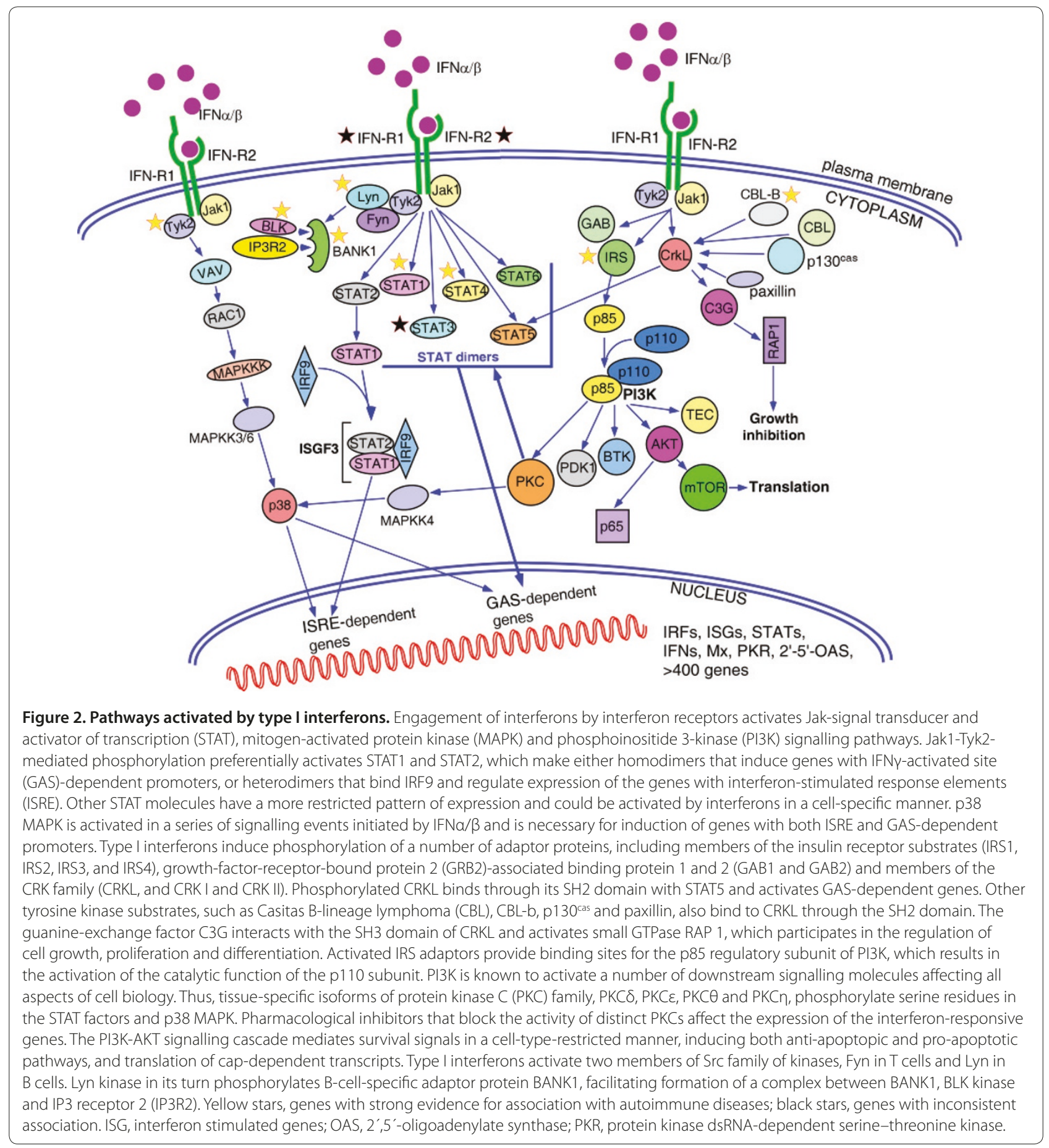

\section{Associations with molecules providing direct downstream signalling from the interferon receptor}

The TYK2 gene was reported as associated with SLE in the same study that revealed the association for IRF5 [69]. Unlike IRF5, the first replication attempts where controversial [141], but to date many more studies have confirmed TYK2 as a susceptibility locus for SLE and it has also been incriminated in multiple sclerosis susceptibility $[86,142,143]$. Furthermore, a recent study in Finnish patients with SLE found significant evidence for interaction between rs2304256 in TYK2 and rs10954213 in IRF5 [142]. No functional polymorphism in $T Y K 2$, however, has yet been described.

Among the STAT genes, only STAT4 is reported to be associated with several autoimmune disorders in Caucasian populations [144-150], Hispanic populations 
$[146,151]$ and Asian populations [152-155]. STAT4 is expressed mainly in T cells, NK cells, activated monocytes and dendritic cells [156], where it resides in the cytoplasm in its inactive form. Upon cell activation with IL-12, IL-23 or IFN $\alpha / \beta$, STAT4 becomes phosphorylated by tyrosine kinases, forms homodimers and translocates into the nucleus, where it induces expression of IFNy [157]. STAT4 is essential for differentiation of naïve CD4 ${ }^{+}$ $\mathrm{T}$ cells into T-helper type 1 cells [158-160]. STAT4 maps to human chromosome 2q32.2 next to STAT1 in a headto-tail mode with moderate LD between them, which could account for the weak association signal for STAT1 detected in multiple sclerosis [161] and SLE [144]. STAT3 was recently reported to be associated with Crohn's disease [162].

Currently, the strongest and more replicated association signal within STAT4 is located in the third intron of the gene $[144,147,148,152]$. We reported an independent association with a haplotype covering the region from exons 6 to 16, which represents the strongest effect within STAT4 for Argentineans and Spanish patients with SLE, while the intron 3 variants have the strongest effect in Italians and Germans [144]. This populationspecific haplotype effect was independently confirmed by a study in SLE patients of Hispanic and AfricanAmerican origin. This study revealed differences in the haplotype structure of STAT4 between populations: the LD between the two associated haplotype blocks (the intron 3 haplotype and the exon 6 to 16 haplotype) is lower in non-European populations compared with European-derived populations [146]. The frequency of this haplotype is much higher in Hispanics compared with Europeans $[144,146]$. It has been demonstrated that the intron 3 association is particularly stronger in patients with anti-dsDNA autoantibodies, nephritis and early disease onset $[148,152,163]$. The reported allelic heterogeneity of STAT4 might thus either be reflecting true population differences or these two haplotypes could be important in different clinical and/or serological subsets of patients.

The STAT4 haplotype risk correlates with higher levels of STAT4 expression, which seems to be cell specific $[144,148]$. Besides, the tissue-specific alternative promoters identified for STAT4 suggest a more complex regulation of the gene, which poses an additional obstacle in the search for the causative variants and their effects. One recent study reported a striking correlation between the risk allele of SNP rs7574865 and increased expression of interferon-induced genes in the absence of high amounts of interferon [164]. This increased expression may lead to a lower threshold for disease initiation. Moreover, the disease-associated alleles for IRF5 and STAT4 variants have an additive effect on the risk for SLE $[144,148]$. Interestingly, STAT4 expression - unlike any other STAT genes - is restricted mainly to T cells and NK cells, and in this respect it is reminiscent of the very limited expression pattern for IRF5 [165]. Further re-sequencing of STAT4 might be necessary in order to identify the true functional variants.

\section{Associations with genes modulated by type I interferons}

Although some genes and their products may not directly participate in the signalling from the interferon type I receptors, they still may be regulated by interferons and comprise a large group of genes included in the interferon signature pattern. We will focus on two genes/proteins modulated by type I interferon, Src-family tyrosine kinase $B L K$ and adaptor protein $B A N K 1$, because they are confirmed SLE susceptibility loci as identified by genome-wide association studies, both are specific for B cells and their expression in B cells is modulated by type I interferons [145,166]. To date, the association of $B L K$ with SLE has been replicated in European [149], Japanese [167] and Chinese [155] populations, and it has also been implicated in RA [168] and primary anti-phospholipid syndrome [169]. The risk allele of the SNP rs13277113, located in the promoter region of $B L K$, is negatively correlated with the levels of $B L K$. It has also been shown that treatment with IFN $\alpha$ rapidly downregulates expression of $B L K$ and, moreover, its expression is negatively regulated by infection with Epstein-Barr virus, which has been suggested as one of the environmental triggers for autoimmune diseases [170]. Low levels of $B L K$, determined by the risk allele, exposure to high amounts of interferon, and infection with Epstein-Barr virus altogether might therefore exert a cumulative effect on risk through negative regulation of BLK in B cells.

$B A N K 1$ association was identified in Scandinavian patients with SLE [166] and further replicated in European Americans $[86,149,171]$ and Chinese populations [172]. It has also been incriminated in RA, although with a less strong effect size [173]. Three disease-associated variants have been described: rs10516487 (R61H) located in exon 2; rs17266594, which is in strong LD with rs10516487 $\left(r^{2}=\right.$ 0.90 ) and is located in intron 2 , where it alters the branchpoint site; and an independent signal in exon 7 coding for an ankyrin domain (rs3733197, A383T) [166]. The variation at the branch-point site alters the efficiency of splicing of exon 2. The risk allele of rs17266594 correlates with high levels of the full-length isoform and low levels of the alternative isoform lacking the entire exon 2, which codes for a putative binding domain for inositol 1,4,5-triphosphate receptor type 2 (IP3R2), known to associate with BANK1 upon B-cell activation [174].

We have observed that polymorphisms of BANK1, BLK and ITPR2 genes display statistical genetic interaction, increasing substantially the risk to develop SLE (Castillejo-Lopez C, Delgado-Vega AM, Wojcik J, et al., 
submitted data) [175]. Interestingly, $L Y N$ - another B-cell-specific tyrosine kinase recently associated with SLE [85,176] - may activate BANK1 through phosphorylation, leading to further stimulation of its interaction with IP3R2. Reduced levels of LYN were also detected in B cells of lupus patients [177]. Of note, expression of $B A N K 1$ in B cells is upregulated by type I interferons and, together with decreased levels of either of the kinases LYN or BLK, may significantly distort the signalling and lead to increased production of autoantibodies - although the precise role for the adaptor protein BANK1 in B cells is awaiting elucidation.

\section{Conclusion}

Autoimmune diseases are caused by the breakdown of self-tolerance and are characterized by persistent activation of immune cells, leading to histopathological damage in the absence of an ongoing infection or other discernible cause [178]. These diseases have complex genetic heritability with many genes giving modest contributions to the disease initiation and perpetuation. Given the role of type I interferons in autoimmunity, the associated genetic variants that have been reviewed in the present article are believed to lead either to the excessive production of interferons and further amplification of the deleterious interferon-mediated signalling, or to impaired negative regulation of the interferon pathways, or to abnormal response to interferons caused by the increased sensitivity of cells. Remarkably, the most strongly associated genes, such as IRF5 and STAT4, are not only replicated in many populations, but also predispose to various autoimmune diseases. On the other hand, genes with weaker signals are rather associated with specific clinical manifestations; that is, they affect only specific subsets of patients with particular disease, and as such may be considered disease modifiers rather than true susceptibility genes.

Based on the two most studied examples - IRF5 and STAT4 - it is tempting to speculate that common shared genes are located in the major knots of the signalling cascades. The current lack of data on association of a particular gene, already found to be associated with a specific disease, with other autoimmune diseases, however, does not mean a lack of association per se. Given the generally low prevalence of autoimmune diseases, it is often a challenging task to collect a large enough number of patients with another autoimmune disease from the same population. It is possible also that complex epistatic interactions hinder genetic associations, and thus will require more detailed analysis of an individual's genotypes for various genes.

Another complication was recently highlighted by the finding that rare mutations or copy number variations may lead to the development of autoimmune diseases.
Rare nonsense mutations have been detected in the DNASE1 gene in two Japanese SLE patients [179]. A number of rare mutations associated with SLE and Sjogren's syndrome were identified recently for another nuclease, TREX1 [180,181]. Likewise, protection against type 1 diabetes was associated with four rare variants in the IFIH1 gene [10]. This highlights the challenge of gene re-sequencing and the importance of projects like the 1000 genomes [182] in order to find noncommon variants with highly penetrant effects in autoimmune diseases.

Despite the fact that interferons are linked to many diseases, the exact role of different types of interferons in various autoimmune diseases may be different, or even opposite. While treatment with recombinant interferons is known to ameliorate multiple sclerosis, it triggers the development of SLE, type 1 diabetes, psoriasis, inflammatory arthritis and pSS $[39,40]$. The genes and alleles associated with distinct diseases in connection with interferon-mediated pathways could therefore obviously be different.

\section{Abbreviations}

anti-RNP = anti-RNA-binding proteins; dsRNA = double-stranded RNA; $\mathrm{F} c \gamma \mathrm{R}=\mathrm{Fc}$ gamma receptor; $\mathrm{IC}=$ immune complex; $\mathrm{IFN}=$ interferon; $\mathrm{IL}=$ interleukin; IRF = interferon regulatory factor; $\mathrm{NF}=$ nuclear factor; $\mathrm{NK}=$ natural killer; $\mathrm{LD}=$ linkage disequilibrium; $\mathrm{pDC}$ = plasmacytoid dendritic cell; pSS = primary Sjögren's syndrome; RA = rheumatoid arthritis; SLE = systemic lupus erythematosus; SNP = single nucleotide polymorphism; STAT = signal transducer and activator of transcription; TLR = Toll-like receptor; TNF = tumour necrosis factor; UTR = untranslated region.

Competing interests

The authors declare that they have no competing interests.

\section{Acknowledgements}

The present project was supported in part by the Clas Groschinskys foundation, the Swedish Association Against Rheumatism to SVK and MEA-R, the Torsten and Ragnar Söderbergs Foundation, the Swedish Research Council, and the Gustaf Vth, 80th Jubilee to MEA-R. The authors would like to acknowledge also the support from National Institutes of Health grants RR020143, Al083194, CA141700 and AR058621 to MEA-R.

This article is part of Arthritis Research \& Therapy Volume 12 Supplement 1: The role of IFN alpha in autoimmune disease. The full contents of the supplement are available online at http://arthritis-research.com/supplements/12/S1. Publication of the supplement has been supported with funding from Medlmmune, LLC.

\section{Author details}

'Department of Genetics and Pathology, Rudbeck Laboratory, Uppsala University, Dag Hammarskjölds väg 20, 75185 Uppsala, Sweden. ${ }^{2}$ Arthritis and Immunology Program, Oklahoma Medical Research Foundation, 825 NE 13th Street, Oklahoma City, OK 73104, USA. ${ }^{3}$ Andalucian Center for Genomics and Oncological Research Pfizer-University of Granada-Junta de Andalucía, Parque Tecnologico Ciencias de la Salud, Avda. Conocimiento S/N, 18100 Armilla, Granada, Spain.

Published: 14 April 2010

References

1. Pestka S, Krause CD, Walter MR: Interferons, interferon-like cytokines, and their receptors. Immunol Rev 2004, 202:8-32.

2. Jaks E, Gavutis M, Uze G, Martal J, Piehler J: Differential receptor subunit affinities of type I interferons govern differential signal activation. J Mol Biol 2007, 366:525-539. 
3. Diaz MO, Pomykala HM, Bohlander SK, Maltepe E, Malik K, Brownstein B, Olopade OI: Structure of the human type-I interferon gene cluster determined from a YAC clone contig. Genomics 1994, 22:540-552.

4. Luft T, Pang KC, Thomas E, Hertzog P, Hart DN, Trapani J, Cebon J: Type I IFNs enhance the terminal differentiation of dendritic cells. J Immunol 1998, 161:1947-1953.

5. Gallucci S, Lolkema M, Matzinger P: Natural adjuvants: endogenous activators of dendritic cells. Nat Med 1999, 5:1249-1255.

6. Montoya M, Schiavoni G, Mattei F, Gresser I, Belardelli F, Borrow P, Tough DF: Type I interferons produced by dendritic cells promote their phenotypic and functional activation. Blood 2002, 99:3263-3271.

7. Ito T, Amakawa R, Inaba M, Ikehara S, Inaba K, Fukuhara S: Differential regulation of human blood dendritic cell subsets by IFNs. J Immuno/ 2001, 166:2961-2969

8. Ito T, Kanzler H, Duramad O, Cao W, Liu YJ: Specialization, kinetics, and repertoire of type 1 interferon responses by human plasmacytoid predendritic cells. Blood 2006, 107:2423-2431.

9. Jego G, Palucka AK, Blanck JP, Chalouni C, Pascual V, Banchereau J: Plasmacytoid dendritic cells induce plasma cell differentiation through type I interferon and interleukin 6. Immunity 2003, 19:225-234.

10. Nejentsev S, Walker N, Riches D, Egholm M, Todd JA: Rare variants of IFIH1, a gene implicated in antiviral responses, protect against type 1 diabetes. Science 2009, 324:387-389.

11. Moore PA, Belvedere O, Orr A, Pieri K, LaFleur DW, Feng P, Soppet D, Charters M, Gentz R, Parmelee D, Li Y, Galperina O, Giri J, Roschke V, Nardelli B, Carrell J, Sosnovtseva S, Greenfield W, Ruben SM, Olsen HS, Fikes J, Hilbert DM: BLyS: member of the tumor necrosis factor family and B lymphocyte stimulator. Science 1999, 285:260-263.

12. Litinskiy MB, Nardelli B, Hillbert DM, He B, Schaffer A, Casali P, Cerutti A: DCs induce CD40-independent immunoglobulin class switching through BLyS and APRIL. Nat Immunol 2002, 3:822-829.

13. Decalf J, Fernandes S, Longman R, Ahloulay M, Audat F, Lefrerre F, Rice CM, Pol S, Albert ML: Plasmacytoid dendritic cells initiate a complex chemokine and cytokine network and are a viable drug target in chronic HCV patients. J Exp Med 2007, 204:2423-2437.

14. Krug A, Towarowski A, Britsch S, Rothenfusser S, Hornung V, Bals R, Giese T, Engelmann H, Endres S, Krieg AM, Hartmann G: Toll-like receptor expression reveals $\mathrm{CpG}$ DNA as a unique microbial stimulus for plasmacytoid dendritic cells which synergizes with CD40 ligand to induce high amounts of IL-12. Eur J Immunol 2001, 31:3026-3037.

15. Piqueras B, Connolly J, Freitas H, Palucka AK, Banchereau J: Upon viral exposure, myeloid and plasmacytoid dendritic cells produce 3 waves of distinct chemokines to recruit immune effectors. Blood 2006 107:2613-2618

16. Penna G, Vulcano M, Roncari A, Facchetti F, Sozzani S, Adorini L: Cutting edge: differential chemokine production by myeloid and plasmacytoid dendritic cells. J Immuno/ 2002, 169:6673-6676.

17. Megjugorac NJ, Young HA, Amrute SB, Olshalsky SL, Fitzgerald-Bocarsly P: Virally stimulated plasmacytoid dendritic cells produce chemokines and induce migration of T and NK cells. J Leukoc Biol 2004, 75:504-514

18. Curtsinger JM, Valenzuela JO, Agarwal P, Lins D, Mescher MF: Type I IFNs provide a third signal to CD8 T cells to stimulate clonal expansion and differentiation. J Immuno/ 2005, 174:4465-4469.

19. Le Bon A, Schiavoni G, D'Agostino G, Gresser I, Belardelli F, Tough DF: Type I interferons potently enhance humoral immunity and can promote isotype switching by stimulating dendritic cells in vivo. Immunity 2001, 14:461-470.

20. Gisler RH, Lindahl P, Gresser I: Effects of interferon on antibody synthesis in vitro. J Immunol 1974, 113:438-444.

21. Peters $M$, Ambrus JL, Zheleznyak A, Walling D, Hoofnagle JH: Effect of interferon-alpha on immunoglobulin synthesis by human B cells. J Immunol 1986, 137:3153-3157.

22. Braun D, Caramalho I, Demengeot J: IFN-alpha/beta enhances BCR-dependent B cell responses. Int Immuno/ 2002, 14:411-419.

23. Morikawa K, Kubagawa H, Suzuki T, Cooper MD: Recombinant interferonalpha, -beta, and -gamma enhance the proliferative response of human B cells. J Immuno/ 1987, 139:761-766.

24. Le Bon A, Thompson C, Kamphuis E, Durand V, Rossmann C, Kalinke U, Tough DF: Cutting edge: enhancement of antibody responses through direct stimulation of B and T cells by type I IFN. J Immunol 2006, 176:2074-2078.

25. Marrack P, Kappler J, Mitchell T: Type I interferons keep activated T cells alive. J Exp Med 1999, 189:521-530

26. Ruuth $\mathrm{K}$, Carlsson L, Hallberg B, Lundgren E: Interferon-alpha promotes survival of human primary B-lymphocytes via phosphatidylinositol 3-kinase. Biochem Biophys Res Commun 2001, 284:583-586.

27. von Hoegen P, Zawatzky R, Schirrmacher V: Modification of tumor cells by a low dose of Newcastle disease virus. III. Potentiation of tumor-specific cytolytic T cell activity via induction of interferon-alpha/beta. Cell Immunol 1990, 126:80-90

28. Kolumam GA, Thomas S, Thompson LJ, Sprent J, Murali-Krishna K: Type I interferons act directly on CD8 T cells to allow clonal expansion and memory formation in response to viral infection. J Exp Med 2005, 202:637-650

29. Lee CK, Rao DT, Gertner R, Gimeno R, Frey AB, Levy DE: Distinct requirements for IFNs and STAT1 in NK cell function. J Immunol 2000, 165:3571-3577.

30. Kamath AT, Sheasby CE, Tough DF: Dendritic cells and NK cells stimulate bystander T cell activation in response to TLR agonists through secretion of IFN-alpha beta and IFN-gamma. J Immunol 2005, 174:767-776.

31. Fernandez NC, Lozier A, Flament C, Ricciardi-Castagnoli P, Bellet D, Suter M, Perricaudet M, Tursz T, Maraskovsky E, Zitvogel L: Dendritic cells directly trigger NK cell functions: cross-talk relevant in innate anti-tumor immune responses in vivo. Nat Med 1999, 5:405-411.

32. Gerosa F, Gobbi A, Zorzi P, Burg S, Briere F, Carra G, Trinchieri G: The reciprocal interaction of NK cells with plasmacytoid or myeloid dendritic cells profoundly affects innate resistance functions. J Immuno/ 2005 , 174:727-734.

33. Blanco P, Palucka AK, Gill M, Pascual V, Banchereau J: Induction of dendritic cell differentiation by IFN-alpha in systemic lupus erythematosus. Science 2001, 294:1540-1543

34. Hooks JJ, Moutsopoulos HM, Geis SA, Stahl NI, Decker JL, Notkins AL: Immune interferon in the circulation of patients with autoimmune disease. N Engl J Med 1979, 301:5-8.

35. Preble OT, Black RJ, Friedman RM, Klippel JH, Vilcek J: Systemic lupus erythematosus: presence in human serum of an unusual acid-labile leukocyte interferon. Science 1982, 216:429-431.

36. Ytterberg SR, Schnitzer TJ: Serum interferon levels in patients with systemic lupus erythematosus. Arthritis Rheum 1982, 25:401-406.

37. Niewold TB, Hua J, Lehman TJ, Harley JB, Crow MK: High serum IFN-alpha activity is a heritable risk factor for systemic lupus erythematosus. Genes Immun 2007, 8:492-502.

38. Hooks JJ, Jordan GW, Cupps T, Moutsopoulos HM, Fauci AS, Notkins AL: Multiple interferons in the circulation of patients with systemic lupus erythematosus and vasculitis. Arthritis Rheum 1982, 25:396-400.

39. Gota C, Calabrese L: Induction of clinical autoimmune disease by therapeutic interferon-alpha. Autoimmunity 2003, 36:511-518.

40. Ronnblom LE, Alm GV, Oberg KE: Autoimmunity after alpha-interferon therapy for malignant carcinoid tumors. Ann Intern Med 1991, 115:178-183.

41. Baechler EC, Batliwalla FM, Karypis G, Gaffney PM, Ortmann WA, Espe KJ, Shark KB, Grande WJ, Hughes KM, Kapur V, Gregersen PK, Behrens TW: Interferon-inducible gene expression signature in peripheral blood cells of patients with severe lupus. Proc Natl Acad SciU S A 2003, 100:2610-2615.

42. Alarcon-Segovia D: Shared autoimmunity: a concept for which the time has come. Autoimmunity 2005, 38:201-203.

43. Baechler EC, Batliwalla FM, Reed AM, Peterson EJ, Gaffney PM, Moser KL, Gregersen PK, Behrens TW: Gene expression profiling in human autoimmunity. Immunol Rev 2006, 210:120-137.

44. Siegal FP, Kadowaki N, Shodell M, Fitzgerald-Bocarsly PA, Shah K, Ho S, Antonenko S, Liu YJ: The nature of the principal type 1 interferonproducing cells in human blood. Science 1999, 284:1835-1837.

45. Cella M, Jarrossay D, Facchetti F, Alebardi O, Nakajima H, Lanzavecchia A, Colonna M: Plasmacytoid monocytes migrate to inflamed lymph nodes and produce large amounts of type I interferon. Nat Med 1999, 5:919-923.

46. Rahman AH, Eisenberg RA: The role of toll-like receptors in systemic lupus erythematosus. Springer Semin Immunopathol 2006, 28:131-143.

47. Hornung V, Rothenfusser S, Britsch S, Krug A, Jahrsdorfer B, Giese T, Endres S, Hartmann G: Quantitative expression of toll-like receptor 1-10 mRNA in cellular subsets of human peripheral blood mononuclear cells and sensitivity to CpG oligodeoxynucleotides. I Immuno/ 2002, 168:4531-4537.

48. Heil F, Hemmi H, Hochrein H, Ampenberger F, Kirschning C, Akira S, Lipford G, Wagner $\mathrm{H}$, Bauer S: Species-specific recognition of single-stranded RNA via toll-like receptor 7 and 8. Science 2004, 303:1526-1529.

49. Kadowaki N, Ho S, Antonenko S, Malefyt RW, Kastelein RA, Bazan F, Liu YJ: 
Subsets of human dendritic cell precursors express different toll-like receptors and respond to different microbial antigens. J Exp Med 2001, 194:863-869.

50. Birmachu W, Gleason RM, Bulbulian BJ, Riter CL, Vasilakos JP, Lipson KE, Nikolsky Y: Transcriptional networks in plasmacytoid dendritic cells stimulated with synthetic TLR 7 agonists. BMC Immunol 2007, 8:26.

51. Kawai T, Adachi O, Ogawa T, Takeda K, Akira S: Unresponsiveness of MyD88deficient mice to endotoxin. Immunity 1999, 11:115-122.

52. Yoneyama M, Kikuchi M, Natsukawa T, Shinobu N, Imaizumi T, Miyagishi M, Taira K, Akira S, Fujita T: The RNA helicase RIG-I has an essential function in double-stranded RNA-induced innate antiviral responses. Nat Immunol 2004, 5:730-737.

53. Kang DC, Gopalkrishnan RV, Wu Q, Jankowsky E, Pyle AM, Fisher PB: mda-5: an interferon-inducible putative RNA helicase with double-stranded RNAdependent ATPase activity and melanoma growth-suppressive properties. Proc Natl Acad Sci U S A 2002, 99:637-642.

54. Garcia MA, Meurs EF, Esteban M: The dsRNA protein kinase PKR: virus and cell control. Biochimie 2007, 89:799-811.

55. Hovanessian AG, Justesen J: The human 2'-5'oligoadenylate synthetase family: unique interferon-inducible enzymes catalyzing 2' -5 ' instead of 3'-5' phosphodiester bond formation. Biochimie 2007, 89:779-788.

56. Ishii KJ, Kawagoe T, Koyama S, Matsui K, Kumar H, Kawai T, Uematsu S, Takeuchi O, Takeshita F, Coban C, Akira S: TANK-binding kinase-1 delineates innate and adaptive immune responses to DNA vaccines. Nature 2008, 451:725-729.

57. Fernandes-Alnemri T, Yu JW, Datta P, Wu J, Alnemri ES: AIM2 activates the inflammasome and cell death in response to cytoplasmic DNA. Nature 2009, 458:509-513.

58. Hornung V, Ablasser A, Charrel-Dennis M, Bauernfeind F, Horvath G, Caffrey DR, Latz E, Fitzgerald KA: AIM2 recognizes cytosolic dsDNA and forms a caspase-1-activating inflammasome with ASC. Nature 2009, 458:514-518.

59. Roberts TL, Idris A, Dunn JA, Kelly GM, Burnton CM, Hodgson S, Hardy LL, Garceau V, Sweet MJ, Ross IL, Hume DA, Stacey KJ: HIN-200 proteins regulate caspase activation in response to foreign cytoplasmic DNA. Science 2009, 323:1057-1060

60. Burckstummer T, Baumann C, Bluml S, Dixit E, Durnberger G, Jahn H, Planyavsky M, Bilban M, Colinge J, Bennett KL, Superti-Furga G: An orthogonal proteomic-genomic screen identifies AIM2 as a cytoplasmic DNA sensor for the inflammasome. Nat Immuno/ 2009, 10:266-272.

61. Muruve DA, Petrilli V, Zaiss AK, White LR, Clark SA, Ross PJ, Parks RJ, Tschopp J: The inflammasome recognizes cytosolic microbial and host DNA and triggers an innate immune response. Nature 2008, 452:103-107.

62. Lee HK, Lund JM, Ramanathan B, Mizushima N, Iwasaki A: Autophagydependent viral recognition by plasmacytoid dendritic cells. Science 2007 , 315:1398-1401

63. Barnes BJ, Field AE, Pitha-Rowe PM: Virus-induced heterodimer formation between IRF-5 and IRF-7 modulates assembly of the IFNA enhanceosome in vivo and transcriptional activity of IFNA genes. J Biol Chem 2003, 278:16630-16641.

64. Barnes BJ, Kellum MJ, Field AE, Pitha PM: Multiple regulatory domains of IRF-5 control activation, cellular localization, and induction of chemokines that mediate recruitment of T lymphocytes. Mol Cell Biol 2002, 22:5721-5740

65. Barnes BJ, Kellum MJ, Pinder KE, Frisancho JA, Pitha PM: Interferon regulatory factor 5 , a novel mediator of cell cycle arrest and cell death. Cancer Res 2003, 63:6424-6431

66. Barnes BJ, Moore PA, Pitha PM: Virus-specific activation of a novel interferon regulatory factor, IRF-5, results in the induction of distinct interferon alpha genes. J Biol Chem 2001, 276:23382-23390.

67. Izaguirre A, Barnes BJ, Amrute S, Yeow WS, Megjugorac N, Dai J, Feng D, Chung E, Pitha PM, Fitzgerald-Bocarsly P: Comparative analysis of IRF and IFN-alpha expression in human plasmacytoid and monocyte-derived dendritic cells. J Leukoc Biol 2003, 74:1125-1138.

68. Graham RR, Kozyrev SV, Baechler EC, Reddy MV, Plenge RM, Bauer JW, Ortmann WA, Koeuth T, Gonzalez Escribano MF, Pons-Estel B, Petri M, Daly M, Gregersen PK, Martin J, Altshuler D, Behrens TW, Alarcon-Riquelme ME: A common haplotype of interferon regulatory factor 5 (IRF5) regulates splicing and expression and is associated with increased risk of systemic lupus erythematosus. Nat Genet 2006, 38:550-555.

69. Sigurdsson S, Nordmark G, Goring HH, Lindroos K, Wiman AC, Sturfelt G, Jonsen A, Rantapaa-Dahlqvist S, Moller B, Kere J, Koskenmies S, Widen E,
Eloranta ML, Julkunen H, Kristjansdottir H, Steinsson K, Alm G, Ronnblom L, Syvanen AC: Polymorphisms in the tyrosine kinase 2 and interferon regulatory factor 5 genes are associated with systemic lupus erythematosus. Am J Hum Genet 2005, 76:528-537.

70. Sigurdsson S, Padyukov L, Kurreeman FA, Liljedahl U, Wiman AC, Alfredsson L, Toes R, Ronnelid J, Klareskog L, Huizinga TW, Alm G, Syvanen AC, Ronnblom $L:$ Association of a haplotype in the promoter region of the interferon regulatory factor 5 gene with rheumatoid arthritis. Arthritis Rheum 2007, 56:2202-2210.

71. Miceli-Richard C, Comets E, Loiseau P, Puechal X, Hachulla E, Mariette X: Association of an IRF5 gene functional polymorphism with Sjogren's syndrome. Arthritis Rheum 2007, 56:3989-3994.

72. Dideberg V, Kristjansdottir G, Milani L, Libioulle C, Sigurdsson S, Louis E, Wiman AC, Vermeire S, Rutgeerts P, Belaiche J, Franchimont D, Van Gossum A Bours V, Syvanen AC: An insertion-deletion polymorphism in the interferon regulatory factor 5 (IRF5) gene confers risk of inflammatory bowel diseases. Hum Mol Genet 2007, 16:3008-3016.

73. Kristjansdottir G, Sandling JK, Bonetti A, Roos IM, Milani L, Wang C Gustafsdottir SM, Sigurdsson S, Lundmark A, Tienari PJ, Koivisto K, Elovaara I, Pirttila T, Reunanen M, Peltonen L, Saarela J, Hillert J, Olsson T, Landegren U, Alcina A, Fernandez O, Leyva L, Guerrero M, Lucas M, Izquierdo G, Matesanz F, Syvanen AC: Interferon regulatory factor 5 (IRF5) gene variants are associated with multiple sclerosis in three distinct populations. J Med Genet 2008, 45:362-369.

74. Sigurdsson S, Goring HH, Kristjansdottir G, Milani L, Nordmark G, Sandling JK Eloranta ML, Feng D, Sangster-Guity N, Gunnarsson I, Svenungsson E, Sturfelt G, Jonsen A, Truedsson L, Barnes BJ, Alm G, Ronnblom L, Syvanen AC: Comprehensive evaluation of the genetic variants of interferon regulatory factor 5 (IRF5) reveals a novel 5 bp length polymorphism as strong risk factor for systemic lupus erythematosus. Hum Mol Genet 2008, 17:872-881.

75. Kozyrev SV, Alarcon-Riquelme ME: The genetics and biology of Irf5mediated signaling in lupus. Autoimmunity 2007, 40:591-601.

76. Cunninghame Graham DS, Manku H, Wagner S, Reid J, Timms K, Gutin A, Lanchbury JS, Vyse TJ: Association of IRF5 in UK SLE families identifies a variant involved in polyadenylation. Hum Mol Genet 2007, 16:579-591.

77. Löfgren S, Yin H, Delgado-Vega AM, Sanchez E, Lewén S., Pons-Estel BA, Witte T, D’Alfonso S, Ortego-Centeno N, Martin J, Alarcón-Riquelme ME, Kozyrev SV: Promoter insertion/deletion in the IRF5 gene is highly associated with susceptibility to SLE in distinct populations but exerts a modest effect on gene expression in PBMCs. J Rheumatol 2010, 37:3.

78. Graham RR, Kyogoku C, Sigurdsson S, Vlasova IA, Davies LR, Baechler EC, Plenge RM, Koeuth T, Ortmann WA, Hom G, Bauer JW, Gillett C, Burtt N, Cunninghame Graham DS, Onofrio R, Petri M, Gunnarsson I, Svenungsson E, Ronnblom L, Nordmark G, Gregersen PK, Moser K, Gaffney PM, Criswell LA, Vyse TJ, Syvanen AC, Bohjanen PR, Daly MJ, Behrens TW, Altshuler D: Three functional variants of IFN regulatory factor 5 (IRF5) define risk and protective haplotypes for human lupus. Proc Natl Acad Sci U S A 2007 104:6758-6763.

79. Niewold TB, Kelly JA, Flesch MH, Espinoza LR, Harley JB, Crow MK: Association of the IRF5 risk haplotype with high serum interferon-alpha activity in systemic lupus erythematosus patients. Arthritis Rheum 2008, 58:2481-2487.

80. Reddy MV, Velazquez-Cruz R, Baca V, Lima G, Granados J, Orozco L, AlarconRiquelme ME: Genetic association of IRF5 with SLE in Mexicans: higher frequency of the risk haplotype and its homozygozity than Europeans. Hum Genet 2007, 121:721-727.

81. Kawai T, Akira S: TLR signaling. Cell Death Differ 2006, 13:816-825.

82. Schoenemeyer A, Barnes BJ, Mancl ME, Latz E, Goutagny N, Pitha PM, Fitzgerald KA, Golenbock DT: The interferon regulatory factor, IRF5, is a central mediator of toll-like receptor 7 signaling. J Biol Chem 2005, 280:17005-17012.

83. Takaoka A, Yanai H, Kondo S, Duncan G, Negishi H, Mizutani T, Kano S, Honda $\mathrm{K}$, Ohba Y, Mak TW, Taniguchi T: Integral role of IRF-5 in the gene induction programme activated by Toll-like receptors. Nature 2005, 434:243-249.

84. Calvo-Alen J, Reveille JD, Rodriguez-Valverde V, McGwin G, Jr, Baethge BA, Friedman AW, Alarcon GS: Clinical, immunogenetic and outcome features of Hispanic systemic lupus erythematosus patients of different ethnic ancestry. Lupus 2003, 12:377-385.

85. Harley JB, Alarcon-Riquelme ME, Criswell LA, Jacob CO, Kimberly RP, Moser KL, Tsao BP, Vyse TJ, Langefeld CD, Nath SK, Guthridge JM, Cobb BL, Mirel DB, Marion MC, Williams AH, Divers J, Wang W, Frank SG, Namjou B, Gabriel SB, Lee AT, Gregersen PK, Behrens TW, Taylor KE, Fernando M, Zidovetzki R, 
Gaffney PM, Edberg JC, Rioux JD, Ojwang JO, et al:: Genome-wide association scan in women with systemic lupus erythematosus identifies susceptibility variants in ITGAM, PXK, KIAA1542 and other loci. Nat Genet 2008, 40:204-210

86. Gateva V, Sandling JK, Hom G, Taylor KE, Chung SA, Sun X, Ortmann W, Kosoy R, Ferreira RC, Nordmark G, Gunnarsson I, Svenungsson E, Padyukov L, Sturfelt G, Jonsen A, Bengtsson AA, Rantapaa-Dahlqvist S, Baechler EC, Brown EE, Alarcon GS, Edberg JC, Ramsey-Goldman R, McGwin G, Jr, Reveille JD, Vila LM, Kimberly RP, Manzi S, Petri MA, Lee A, Gregersen PK, et al.: A large-scale replication study identifies TNIP1, PRDM1, JAZF1, UHRF1BP1 and IL10 as risk loci for systemic lupus erythematosus. Nat Genet 2009, 41:1228-1233.

87. International HapMap Project [http://hapmap.ncbi.nIm.nih.gov/]

88. Akahoshi M, Nakashima H, Sadanaga A, Miyake K, Obara K, Tamari M, Hirota T, Matsuda A, Shirakawa T: Promoter polymorphisms in the IRF3 gene confer protection against systemic lupus erythematosus. Lupus 2008, 17:568-574.

89. Sanchez E, Gonzalez-Gay MA, Callejas-Rubio JL, Ortego-Centeno N, Sabio JM, Jimenez-Alonso J, Mico L, Suarez A, Gutierrez C, de Ramon E, Camps M, Garcia-Portales R, Tolosa C, Lopez-Nevot MA, Sanchez-Roman J, Hernandez FJ, Gonzalez-Escribano MF, Martin J: No evidence for genetic association of interferon regulatory factor 3 in systemic lupus erythematosus. Lupus 2009, 18:230-234

90. De Jager PL, Jia X, Wang J, de Bakker PI, Ottoboni L, Aggarwal NT, Piccio L, Raychaudhuri S, Tran D, Aubin C, Briskin R, Romano S, Baranzini SE, McCauley JL, Pericak-Vance MA, Haines JL, Gibson RA, Naeglin Y, Uitdehaag B, Matthews PM, Kappos L, Polman C, McArdle WL, Strachan DP, Evans D, Cross AH, Daly MJ, Compston A, Sawcer SJ, Weiner HL, et al:: Meta-analysis of genome scans and replication identify CD6, IRF8 and TNFRSF1A as new multiple sclerosis susceptibility loci. Nat Genet 2009, 41:776-782.

91. Baldwin AS, Jr: The NF-kappa B and I kappa B proteins: new discoveries and insights. Annu Rev Immunol 1996, 14:649-683.

92. Li Q, Verma IM: NF-KB regulation in the immune system. Nat Rev Immunol 2002, 2:725-734

93. Gregersen PK, Amos Cl, Lee AT, LuY, Remmers EF, Kastner DL, Seldin MF, Criswell LA, Plenge RM, Holers VM, Mikuls TR, Sokka T, Moreland LW, Bridges $S L$, Jr, Xie G, Begovich AB, Siminovitch KA: REL, encoding a member of the NF-kappaB family of transcription factors, is a newly defined risk locus for rheumatoid arthritis. Nat Genet 2009, 41:820-823.

94. Liou HC, Sha WC, Scott ML, Baltimore D: Sequential induction of NF-kappa $\mathrm{B} /$ Rel family proteins during B-cell terminal differentiation. Mol Cell Biol 1994, 14:5349-5359

95. Kontgen F, Grumont RJ, Strasser A, Metcalf D, Li R, Tarlinton D, Gerondakis S: Mice lacking the c-rel proto-oncogene exhibit defects in lymphocyte proliferation, humoral immunity, and interleukin-2 expression. Genes Dev 1995, 9:1965-1977.

96. Owyang AM, Tumang JR, Schram BR, Hsia CY, Behrens TW, Rothstein TL, Liou HC: $c-$ Rel is required for the protection of $B$ cells from antigen receptormediated, but not Fas-mediated, apoptosis. J Immunol 2001, 167:4948-4956.

97. Grumont R, Hochrein H, O'Keeffe M, Gugasyan R, White C, Caminschi I, Cook W, Gerondakis S: c-Rel regulates interleukin 12 p70 expression in CD8(+) dendritic cells by specifically inducing $\mathrm{p} 35$ gene transcription. J Exp Med 2001, 194:1021-1032.

98. Mise-Omata S, Kuroda E, Niikura J, Yamashita U, Obata Y, Doi TS: A proximal kappaB site in the IL-23 p19 promoter is responsible for RelA- and c-Reldependent transcription. J Immunol 2007, 179:6596-6603.

99. Karban AS, Okazaki T, Panhuysen Cl, Gallegos T, Potter JJ, Bailey-Wilson JE, Silverberg MS, Duerr RH, Cho JH, Gregersen PK, Wu Y, Achkar JP, Dassopoulos T, Mezey E, Bayless TM, Nouvet FJ, Brant SR: Functional annotation of a novel NFKB1 promoter polymorphism that increases risk for ulcerative colitis. Hum Mol Genet 2004, 13:35-45.

100. Katarina K, Daniela P, Peter N, Marianna R, Pavlina C, Stepanka P, Jan L, Ludmila T, Michal A, Marie C: HLA, NFKB1 and NFKBIA gene polymorphism profile in autoimmune diabetes mellitus patients. Exp Clin Endocrinol Diabetes 2007, 115:124-129.

101. Kurylowicz A, Hiromatsu Y, Jurecka-Lubieniecka B, Kula D, Kowalska M, Ichimura M, Koga H, Kaku H, Bar-Andziak E, Nauman J, Jarzab B, Ploski R, BednarczukT: Association of NFKB1 -94ins/del ATTG promoter polymorphism with susceptibility to and phenotype of Graves' disease. Genes Immun 2007, 8:532-538.

102. Sha WC, Liou HC, Tuomanen El, Baltimore D: Targeted disruption of the $\mathrm{p} 50$ subunit of NF-kappa B leads to multifocal defects in immune responses.
Cell 1995, 80:321-330

103. Emlen W, Niebur J, Kadera R: Accelerated in vitro apoptosis of lymphocytes from patients with systemic lupus erythematosus. J Immunol 1994, 152:3685-3692.

104. Herrmann M, Voll RE, Zoller OM, Hagenhofer M, Ponner BB, Kalden JR: Impaired phagocytosis of apoptotic cell material by monocyte-derived macrophages from patients with systemic lupus erythematosus. Arthritis Rheum 1998, 41:1241-1250.

105. Karassa FB, Trikalinos TA, loannidis JP: The role of FcgammaRIIA and IIIA polymorphisms in autoimmune diseases. Biomed Pharmacother 2004, 58:286-291.

106. Clark MR, Stuart SG, Kimberly RP, Ory PA, Goldstein IM: A single amino acid distinguishes the high-responder from the low-responder form of $\mathrm{Fc}$ receptor II on human monocytes. Eur J Immuno/ 1991, 21:1911-1916.

107. Fanciulli M, Norsworthy PJ, Petretto E, Dong R, Harper L, Kamesh L, Heward $J M$, Gough SC, de Smith A, Blakemore Al, Froguel P, Owen CJ, Pearce SH, Teixeira L, Guillevin L, Graham DS, Pusey CD, Cook HT, Vyse TJ, Aitman TJ: FCGR3B copy number variation is associated with susceptibility to systemic, but not organ-specific, autoimmunity. Nat Genet 2007 39:721-723.

108. Bave U, Magnusson M, Eloranta ML, Perers A, Alm GV, Ronnblom L: Fc gamma Rlla is expressed on natural IFN-alpha-producing cells (plasmacytoid dendritic cells) and is required for the IFN-alpha production induced by apoptotic cells combined with lupus IgG. J Immuno/ 2003, 171:3296-3302.

109. Magnusson V, Johanneson B, Lima G, Odeberg J, Alarcon-Segovia D, AlarconRiquelme ME: Both risk alleles for FcgammaRIIA and FcgammaRIIIA are susceptibility factors for SLE: a unifying hypothesis. Genes Immun 2004, 5:130-137.

110. Zohar R, Lee W, Arora P, Cheifetz S, McCulloch C, Sodek J: Single cell analysis of intracellular osteopontin in osteogenic cultures of fetal rat calvarial cells. J Cell Physiol 1997, 170:88-100.

111. Shinohara ML, Lu L, Bu J, Werneck MB, Kobayashi KS, Glimcher LH, Cantor H: Osteopontin expression is essential for interferon-alpha production by plasmacytoid dendritic cells. Nat Immunol 2006, 7:498-506.

112. Denhardt DT, Noda M: Osteopontin expression and function: role in bone remodeling. J Cell Biochem Supp/ 1998, 30-31:92-102.

113. Pollack SB, Linnemeyer PA, Gill S: Induction of osteopontin mRNA expression during activation of murine NK cells. J Leukoc Biol 1994 55:398-400.

114. Ashkar S, Weber GF, Panoutsakopoulou V, Sanchirico ME, Jansson M, Zawaideh S, Rittling SR, Denhardt DT, Glimcher MJ, Cantor H: Eta-1 (osteopontin): an early component of type-1 (cell-mediated) immunity. Science 2000, 287:860-864.

115. Lampe MA, Patarca R, Iregui MV, Cantor H: Polyclonal B cell activation by the Eta-1 cytokine and the development of systemic autoimmune disease. J Immunol 1991, 147:2902-2906

116. Scatena M, Liaw L, Giachelli CM: Osteopontin: a multifunctional molecule regulating chronic inflammation and vascular disease. Arterioscler Thromb Vasc Bio/ 2007, 27:2302-2309.

117. Vogt MH, Lopatinskaya L, Smits M, Polman CH, Nagelkerken L: Elevated osteopontin levels in active relapsing-remitting multiple sclerosis. Ann Neurol 2003, 53:819-822.

118. Comabella M, Pericot I, Goertsches R, Nos C, Castillo M, Blas Navarro J, Rio J, Montalban X: Plasma osteopontin levels in multiple sclerosis. J Neuroimmunol 2005, 158:231-239.

119. Chiocchetti A, Indelicato M, Bensi T, Mesturini R, Giordano M, Sametti S, Castelli L, Bottarel F, Mazzarino MC, Garbarini L, Giacopelli F, Valesini G, Santoro C, Dianzani I, Ramenghi U, Dianzani U: High levels of osteopontin associated with polymorphisms in its gene are a risk factor for development of autoimmunity/lymphoproliferation. Blood 2004, 103:1376-1382.

120. Wong CK, Lit LC, Tam LS, Li EK, Lam CW: Elevation of plasma osteopontin concentration is correlated with disease activity in patients with systemic lupus erythematosus. Rheumatology (Oxford) 2005, 44:602-606.

121. Xu G, Nie H, Li N, Zheng W, Zhang D, Feng G, Ni L, Xu R, Hong J, Zhang JZ: Role of osteopontin in amplification and perpetuation of rheumatoid synovitis. J Clin Invest 2005, 115:1060-1067.

122. Masutani K, Akahoshi M, Tsuruya K, Tokumoto M, Ninomiya T, Kohsaka T, Fukuda K, Kanai H, Nakashima H, Otsuka T, Hirakata H: Predominance of Th1 immune response in diffuse proliferative lupus nephritis. Arthritis Rheum 2001, 44:2097-2106. 
123. Ohshima S, Yamaguchi N, Nishioka K, Mima T, Ishii T, Umeshita-Sasai M, Kobayashi H, Shimizu M, Katada Y, Wakitani S, Murata N, Nomura S, Matsuno H, Katayama R, Kon S, Inobe M, Uede T, Kawase I, Saeki Y: Enhanced local production of osteopontin in rheumatoid joints. J Rheumatol 2002, 29:2061-2067.

124. Sato T, Nakai T, Tamura N, Okamoto S, Matsuoka K, Sakuraba A, Fukushima T, Uede T, Hibi T: Osteopontin/Eta-1 upregulated in Crohn's disease regulates the Th1 immune response. Gut 2005, 54:1254-1262.

125. Chabas D, Baranzini SE, Mitchell D, Bernard CC, Rittling SR, Denhardt DT, Sobe RA, Lock C, Karpuj M, Pedotti R, Heller R, Oksenberg JR, Steinman L: The influence of the proinflammatory cytokine, osteopontin, on autoimmune demyelinating disease. Science 2001, 294:1731-1735.

126. Hur EM, Youssef S, Haws ME, Zhang SY, Sobel RA, Steinman L: Osteopontininduced relapse and progression of autoimmune brain disease through enhanced survival of activated T cells. Nat Immunol 2007, 8:74-83.

127. Jansson M, Panoutsakopoulou V, Baker J, Klein L, Cantor H: Cutting edge: Attenuated experimental autoimmune encephalomyelitis in eta-1/ osteopontin-deficient mice. J Immunol 2002, 168:2096-2099.

128. Vogt MH, Floris S, Killestein J, Knol DL, Smits M, Barkhof F, Polman CH, Nagelkerken L: Osteopontin levels and increased disease activity in relapsing-remitting multiple sclerosis patients. J Neuroimmuno/ 2004 155:155-160.

129. Miyazaki T, Ono M, Qu WM, Zhang MC, Mori S, Nakatsuru S, Nakamura Y, Sawasaki T, Endo Y, Nose M: Implication of allelic polymorphism of osteopontin in the development of lupus nephritis in MRL/lpr mice. Eur J Immunol 2005, 35:1510-1520.

130. Forton AC, Petri MA, Goldman D, Sullivan KE: An osteopontin (SPP1) polymorphism is associated with systemic lupus erythematosus. Hum Mutat 2002, 19:459.

131. D’Alfonso S, Barizzone N, Giordano M, Chiocchetti A, Magnani C, Castelli L, Indelicato M, Giacopelli F, Marchini M, Scorza R, Danieli MG, Cappelli M, Migliaresi S, Bigliardo B, Sabbadini MG, Baldissera E, Galeazzi M, Sebastiani GD, Minisola G, Ravazzolo R, Dianzani U, Momigliano-Richiardi P: Two singlenucleotide polymorphisms in the $5^{\prime}$ and $3^{\prime}$ ends of the osteopontin gene contribute to susceptibility to systemic lupus erythematosus. Arthritis Rheum 2005, 52:539-547.

132. Wuthrich RP, Fan X, Ritthaler T, Sibalic V, Yu DJ, Loffing J, Kaissling B: Enhanced osteopontin expression and macrophage infiltration in MRL-Fas(Ipr) mice with lupus nephritis. Autoimmunity 1998, 28:139-150

133. Steinman L, Martin R, Bernard C, Conlon P, Oksenberg JR: Multiple sclerosis: deeper understanding of its pathogenesis reveals new targets for therapy. Annu Rev Neurosci 2002, 25:491-505.

134. Barnes BJ, Richards J, Mancl M, Hanash S, Beretta L, Pitha PM: Global and distinct targets of IRF-5 and IRF-7 during innate response to viral infection. J Biol Chem 2004, 279:45194-45207.

135. Honda K, Yanai H, Negishi H, Asagiri M, Sato M, Mizutani T, Shimada N, Ohba Y, Takaoka A, Yoshida N, Taniguchi T: IRF-7 is the master regulator of type-I interferon-dependent immune responses. Nature 2005, 434:772-777.

136. Han S, Guthridge JM, Harley IT, Sestak AL, Kim-Howard X, Kaufman KM, Namjou B, Deshmukh H, Bruner G, Espinoza LR, Gilkeson GS, Harley JB, James JA, Nath SK: Osteopontin and systemic lupus erythematosus association: a probable gene-gender interaction. PLoS One 2008, 3:e0001757.

137. Kariuki SN, Moore JG, Kirou KA, Crow MK, Utset TO, Niewold TB: Age- and gender-specific modulation of serum osteopontin and interferon-alpha by osteopontin genotype in systemic lupus erythematosus. Genes Immun 2009, 10:487-494

138. Cowley BD, Jr, Ricardo SD, Nagao S, Diamond JR: Increased renal expression of monocyte chemoattractant protein-1 and osteopontin in ADPKD in rats. Kidney Int 2001, 60:2087-2096.

139. Matkovits T, Christakos S: Variable in vivo regulation of rat vitamin D-dependent genes (osteopontin, Ca,Mg-adenosine triphosphatase, and 25-hydroxyvitamin $D_{3}$ 24-hydroxylase): implications for differing mechanisms of regulation and involvement of multiple factors. Endocrinology 1995, 136:3971-3982.

140. Raziuddin A, Sarkar FH, Dutkowski R, Shulman L, Ruddle FH, Gupta SL: Receptors for human alpha and beta interferon but not for gamma interferon are specified by human chromosome 21. Proc Natl Acad Sci U S A 1984, 81:5504-5508

141. Cunninghame Graham DS, Akil M, Vyse TJ: Association of polymorphisms across the tyrosine kinase gene, TYK2 in UK SLE families. Rheumatology (Oxford) 2007, 46:927-930.
142. Hellquist A, Jarvinen TM, Koskenmies S, Zucchelli M, Orsmark-Pietras C, Berglind L, Panelius J, Hasan T, Julkunen H, D'Amato M, Saarialho-Kere U, Kere J: Evidence for genetic association and interaction between the TYK2 and IRF5 genes in systemic lupus erythematosus. J Rheumatol 2009, 36:1631-1638.

143. Ban M, Goris A, Lorentzen AR, Baker A, Mihalova T, Ingram G, Booth DR, Heard RN, Stewart GJ, Bogaert E, Dubois B, Harbo HF, Celius EG, Spurkland A, Strange R, Hawkins C, Robertson NP, Dudbridge F, Wason J, De Jager PL, Hafler D, Rioux JD, Ivinson AJ, McCauley JL, Pericak-Vance M, Oksenberg JR, Hauser SL, Sexton D, Haines J, Sawcer S: Replication analysis identifies TYK2 as a multiple sclerosis susceptibility factor. Eur J Hum Genet 2009, 17:1309-1313.

144. Abelson AK, Delgado-Vega AM, Kozyrev SV, Sanchez E, Velazquez-Cruz R, Eriksson N, Wojcik J, Linga Reddy MV, Lima G, D'Alfonso S, Migliaresi S, Baca V, Orozco L, Witte T, Ortego-Centeno N, Abderrahim H, Pons-Estel BA, Gutierrez C, Suarez A, Gonzalez-Escribano MF, Martin J, Alarcon-Riquelme ME: STAT4 associates with systemic lupus erythematosus through two independent effects that correlate with gene expression and act additively with IRF5 to increase risk. Ann Rheum Dis 2009, 68:1746-1753.

145. Hom G, Graham RR, Modrek B, Taylor KE, Ortmann W, Garnier S, Lee AT, Chung SA, Ferreira RC, Pant PV, Ballinger DG, Kosoy R, Demirci FY, Kamboh MI, Kao AH, Tian C, Gunnarsson I, Bengtsson AA, Rantapaa-Dahlqvist S, Petri M, Manzi S, Seldin MF, Ronnblom L, Syvanen AC, Criswell LA, Gregersen PK, Behrens TW: Association of systemic lupus erythematosus with C8orf13-BLK and ITGAM-ITGAX. N Engl J Med 2008, 358:900-909.

146. Namjou B, Sestak AL, Armstrong DL, Zidovetzki R, Kelly JA, Jacob N, Ciobanu V, Kaufman KM, Ojwang JO, Ziegler J, Quismorio FP, Jr, Reiff A, Myones BL, Guthridge JM, Nath SK, Bruner GR, Mehrian-Shai R, Silverman E, KleinGitelman M, McCurdy D, Wagner-Weiner L, Nocton JJ, Putterman C, Bae SC, Kim YJ, Petri M, Reveille JD, Vyse TJ, Gilkeson GS, Kamen DL, et al.: Highdensity genotyping of STAT4 reveals multiple haplotypic associations with systemic lupus erythematosus in different racial groups. Arthritis Rheum 2009, 60:1085-1095.

147. Remmers EF, Plenge RM, Lee AT, Graham RR, Hom G, Behrens TW, de Bakker PI, Le JM, Lee HS, Batliwalla F, Li W, Masters SL, Booty MG, Carulli JP, Padyukov L, Alfredsson L, Klareskog L, Chen WV, Amos Cl, Criswell LA, Seldin MF, Kastner DL, Gregersen PK: STAT4 and the risk of rheumatoid arthritis and systemic lupus erythematosus. N Engl J Med 2007, 357:977-986.

148. Sigurdsson S, Nordmark G, Garnier S, Grundberg E, Kwan T, Nilsson O, Eloranta ML, Gunnarsson I, Svenungsson E, Sturfelt G, Bengtsson AA, Jonsen A, Truedsson L, Rantapaa-Dahlqvist S, Eriksson C, Alm G, Goring HH, Pastinen T, Syvanen AC, Ronnblom L: A risk haplotype of STAT4 for systemic lupus erythematosus is over-expressed, correlates with anti-dsDNA and shows additive effects with two risk alleles of IRF5. Hum Mol Genet 2008, 17:2868-2876

149. Suarez-Gestal M, Calaza M, Endreffy E, Pullmann R, Ordi-Ros J, Domenico Sebastiani G, Ruzickova S, Jose Santos M, Papasteriades C, Marchini M, Skopouli FN, Suarez A, Blanco FJ, D’Alfonso S, Bijl M, Carreira P, Witte T, Migliaresi S, Gomez-Reino JJ, Gonzalez A: Replication of recently identified systemic lupus erythematosus genetic associations: a case-control study. Arthritis Res Ther 2009, 11:R69.

150. Korman BD, Alba MI, Le JM, Alevizos I, Smith JA, Nikolov NP, Kastner DL, Remmers EF, Illei GG: Variant form of STAT4 is associated with primary Sjogren's syndrome. Genes Immun 2008, 9:267-270.

151. Palomino-Morales RJ, Rojas-Villarraga A, Gonzalez Cl, Ramirez G, Anaya JM, Martin J: STAT4 but not TRAF1/C5 variants influence the risk of developing rheumatoid arthritis and systemic lupus erythematosus in Colombians. Genes Immun 2008, 9:379-382.

152. Kawasaki A, Ito I, Hikami K, Ohashi J, Hayashi T, Goto D, Matsumoto I, Ito S, Tsutsumi A, Koga M, Arinami T, Graham RR, Hom G, Takasaki Y, Hashimoto H, Behrens TW, Sumida T, Tsuchiya N: Role of STAT4 polymorphisms in systemic lupus erythematosus in a Japanese population: a case-control association study of the STAT1-STAT4 region. Arthritis Res Ther 2008, 10:R113.

153. Kobayashi S, Ikari K, Kaneko H, Kochi Y, Yamamoto K, Shimane K, Nakamura Y, Toyama Y, Mochizuki T, Tsukahara S, Kawaguchi Y, Terai C, Hara M, Tomatsu T, Yamanaka H, Horiuchi T, Tao K, Yasutomo K, Hamada D, Yasui N, Inoue H, Itakura M, Okamoto H, Kamatani N, Momohara S: Association of STAT4 with susceptibility to rheumatoid arthritis and systemic lupus erythematosus in the Japanese population. Arthritis Rheum 2008, 58:1940-1946.

154. Lee HS, Remmers EF, Le JM, Kastner DL, Bae SC, Gregersen PK: Association of 
STAT4 with rheumatoid arthritis in the Korean population. Mol Med 2007, 13:455-460.

155. Yang W, Ng P, Zhao M, Hirankarn N, Lau CS, Mok CC, Chan TM, Wong RW, Lee KW, Mok MY, Wong SN, Avihingsanon Y, Lee TL, Ho MH, Lee PP, Wong WH, Lau YL: Population differences in SLE susceptibility genes: STAT4 and BLK, but not PXK, are associated with systemic lupus erythematosus in Hong Kong Chinese. Genes Immun 2009, 10:219-226.

156. Frucht DM, Aringer M, Galon J, Danning C, Brown M, Fan S, Centola M, Wu CY, Yamada N, El Gabalawy H, O'Shea JJ: Stat4 is expressed in activated peripheral blood monocytes, dendritic cells, and macrophages at sites of Th1-mediated inflammation. J Immuno/ 2000, 164:4659-4664.

157. Kaplan MH: STAT4: a critical regulator of inflammation in vivo. Immunol Res 2005, 31:231-242

158. Nishikomori R, Usui T, Wu CY, Morinobu A, O'Shea JJ, Strober W: Activated STAT4 has an essential role in Th1 differentiation and proliferation that is independent of its role in the maintenance of IL-12R beta 2 chain expression and signaling. J Immuno/ 2002, 169:4388-4398.

159. Mathur AN, Chang HC, Zisoulis DG, Stritesky GL, Yu Q, O'Malley JT, Kapur R, Levy DE, Kansas GS, Kaplan MH: Stat3 and Stat4 direct development of IL-17-secreting Th cells. J Immuno/ 2007, 178:4901-4907.

160. Oppmann B, Lesley R, Blom B, Timans JC, Xu Y, Hunte B, Vega F, Yu N, Wang J Singh K, Zonin F, Vaisberg E, Churakova T, Liu M, Gorman D, Wagner J, Zurawski S, Liu Y, Abrams JS, Moore KW, Rennick D, de Waal-Malefyt R, Hannum C, Bazan JF, Kastelein RA: Novel p19 protein engages IL-12p40 to form a cytokine, IL-23, with biological activities similar as well as distinct from IL-12. Immunity 2000, 13:715-725.

161. Fortunato G, Calcagno G, Bresciamorra V, Salvatore E, Filla A, Capone S, Liguori R, Borelli S, Gentile I, Borrelli F, Borgia G, Sacchetti L: Multiple sclerosis and hepatitis $C$ virus infection are associated with single nucleotide polymorphisms in interferon pathway genes. J Interferon Cytokine Res 2008, 28:141-152.

162. Barrett JC, Hansoul S, Nicolae DL, Cho JH, Duerr RH, Rioux JD, Brant SR, Silverberg MS, Taylor KD, Barmada MM, Bitton A, Dassopoulos T, Datta LW, Green T, Griffiths AM, Kistner EO, Murtha MT, Regueiro MD, Rotter Jl, Schumm LP, Steinhart AH, Targan SR, Xavier RJ, Libioulle C, Sandor C, Lathrop M, Belaiche J, Dewit O, Gut I, Heath S, et al:: Genome-wide association defines more than 30 distinct susceptibility loci for Crohn's disease. Nat Genet 2008, 40:955-962.

163. Taylor KE, Remmers EF, Lee AT, Ortmann WA, Plenge RM, Tian C, Chung SA, Nititham J, Hom G, Kao AH, Demirci FY, Kamboh MI, Petri M, Manzi S, Kastner DL, Seldin MF, Gregersen PK, Behrens TW, Criswell LA: Specificity of the STAT4 genetic association for severe disease manifestations of systemic lupus erythematosus. PLoS Genet 2008, 4:e1000084

164. Kariuki SN, Kirou KA, MacDermott EJ, Barillas-Arias L, Crow MK, Niewold TB: Cutting edge: autoimmune disease risk variant of STAT4 confers increased sensitivity to IFN-alpha in lupus patients in vivo. J Immuno/ 2009, 182:34-38.

165. Miyagi T, Gil MP, Wang X, Louten J, Chu WM, Biron CA: High basal STAT4 balanced by STAT1 induction to control type 1 interferon effects in natural killer cells. J Exp Med 2007, 204:2383-2396.

166. Kozyrev SV, Abelson AK, Wojcik J, Zaghlool A, Linga Reddy MV, Sanchez E, Gunnarsson I, Svenungsson E, Sturfelt G, Jonsen A, Truedsson L, Pons-Estel BA, Witte T, D'Alfonso S, Barizzone N, Danieli MG, Gutierrez C, Suarez A, Junker P, Laustrup H, Gonzalez-Escribano MF, Martin J, Abderrahim H, AlarconRiquelme ME: Functional variants in the B-cell gene BANK1 are associated with systemic lupus erythematosus. Nat Genet 2008, 40:211-216.

167. Ito I, Kawasaki A, Ito S, Hayashi T, Goto D, Matsumoto I, Tsutsumi A, Hom G, Graham RR, Takasaki Y, Hashimoto H, Ohashi J, Behrens TW, Sumida T, Tsuchiya N: Replication of the association between the C8orf13-BLK region and systemic lupus erythematosus in a Japanese population. Arthritis Rheum 2009, 60:553-558.

168. Ito I, Kawasaki A, Ito S, Kondo Y, Sugihara M, Horikoshi M, Hayashi T, Goto D, Matsumoto I, Tsutsumi A, Takasaki Y, Hashimoto H, Matsuta K, Sumida T, Tsuchiya N: Replication of association between FAM167A(C8orf13)-BLK region and rheumatoid arthritis in a Japanese population. Ann Rheum Dis 2009:doi:10.1136/ard.2009.118760.

169. Yin $\mathrm{H}$, Borghi MO, Delgado-Vega AM, Tincani A, Meroni PL, Alarcon-Riquelme ME: Association of STAT4 and BLK, but not BANK1 or IRF5, with primary antiphospholipid syndrome. Arthritis Rheum 2009, 60:2468-2471.

170. Portis T, Dyck P, Longnecker R: Epstein-Barr Virus (EBV) LMP2A induces alterations in gene transcription similar to those observed in ReedSternberg cells of Hodgkin lymphoma. Blood 2003, 102:4166-4178.
171. Guo L, Deshmukh H, Lu R, Vidal GS, Kelly JA, Kaufman KM, Dominguez N Klein W, Kim-Howard X, Bruner GR, Scofield RH, Moser KL, Gaffney PM, Dozmorov IM, Gilkeson GS, Wakeland EK, Li QZ, Langefeld CD, Marion MC, Williams AH, Divers J, Alarcon GS, Brown EE, Kimberly RP, Edberg JC, RamseyGoldman R, Reveille JD, McGwin G, Jr, Vila LM, Petri MA, et al:: Replication of the BANK1 genetic association with systemic lupus erythematosus in a European-derived population. Genes Immun 2009, 10:531-538.

172. Chang YK, Yang W, Zhao M, Mok CC, Chan TM, Wong RW, Lee KW, Mok MY, Wong SN, Ng IO, Lee TL, Ho MH, Lee PP, Wong WH, Lau CS, Sham PC, Lau YL: Association of BANK1 and TNFSF4 with systemic lupus erythematosus in Hong Kong Chinese. Genes Immun 2009, 10:414-420.

173. Orozco G, Abelson AK, Gonzalez-Gay MA, Balsa A, Pascual-Salcedo D, Garcia A, Fernandez-Gutierrez B, Petersson I, Pons-Estel B, Eimon A, Paira S, Scherbarth HR, Alarcon-Riquelme M, Martin J: Study of functional variants of the BANK1 gene in rheumatoid arthritis. Arthritis Rheum 2009, 60:372-379.

174. Yokoyama K, Su Ih IH, Tezuka T, Yasuda T, Mikoshiba K, Tarakhovsky A, Yamamoto T: BANK regulates BCR-induced calcium mobilization by promoting tyrosine phosphorylation of IP(3) receptor. EMBO J 2002 21:83-92.

175. Delgado-Vega AM, Castillejo-López C, Wojcik J, Kozyrev S, Sánchez E, Pöllmann D, López-Egido JR, Fineschi S, Domínquez N, Lu R, James JA, Merrill JT, Kelly JA, Kaufman KM, Moser K, Gilkeson G, Frostegård J, Pons-Estel BA, D'Alfonso S, Witte T, Callejas JL, Harley J, Gaffney P, Martin J, Guthridge JM, Alarcón-Riquelme ME: Genetic interactions reveal a novel B-cell pathway in systemic lupus erythematosus [abstract/presentation \#272]. In Proceedings of the 59th Annual Meeting of The American Society of Human Genetics; October 24 2009; Honolulu, HI. The American Society of Human Genetics, Bethesda, MD, USA; 2009: Available at http://www.ashg.org/2009meeting/abstracts/ fulltext/

176. Lu R, Vidal GS, Kelly JA, Delgado-Vega AM, Howard XK, Macwana SR, Dominguez N, Klein W, Burrell C, Harley IT, Kaufman KM, Bruner GR, Moser KL, Gaffney PM, Gilkeson GS, Wakeland EK, Li QZ, Langefeld CD, Marion MC, Divers J, Alarcon GS, Brown EE, Kimberly RP, Edberg JC, Ramsey-Goldman R, Reveille JD, McGwin G, Jr, Vila LM, Petri MA, Bae SC, et al:: Genetic associations of LYN with systemic lupus erythematosus. Genes Immun 2009, 10:397-403.

177. Flores-Borja F, Kabouridis PS, Jury EC, Isenberg DA, Mageed RA: Decreased Lyn expression and translocation to lipid raft signaling domains in $B$ lymphocytes from patients with systemic lupus erythematosus. Arthritis Rheum 2005, 52:3955-3965.

178. Davidson A, Diamond B: Autoimmune diseases. N Engl J Med 2001, 345:340-350.

179. Yasutomo K, Horiuchi T, Kagami S, Tsukamoto H, Hashimura C, Urushihara M, Kuroda Y: Mutation of DNASE1 in people with systemic lupus erythematosus. Nat Genet 2001, 28:313-314.

180. Lee-Kirsch MA, Gong M, Chowdhury D, Senenko L, Engel K, Lee YA, de Silva U, Bailey SL, Witte T, Vyse TJ, Kere J, Pfeiffer C, Harvey S, Wong A, Koskenmies S, Hummel O, Rohde K, Schmidt RE, Dominiczak AF, Gahr M, Hollis T, Perrino FW, Lieberman J, Hubner N: Mutations in the gene encoding the $3^{\prime}-5^{\prime}$ DNA exonuclease TREX 1 are associated with systemic lupus erythematosus. Nat Genet 2007, 39:1065-1067.

181. Kavanagh D, Spitzer D, Kothari PH, Shaikh A, Liszewski MK, Richards A Atkinson JP: New roles for the major human 3'-5' exonuclease TREX1 in human disease. Cell Cycle 2008, 7:1718-1725.

182. 1000 Genomes Project [http://www.1000genomes.org/]

183. Smyth DJ, Cooper JD, Bailey R, Field S, Burren O, Smink LJ, Guja C, lonescuTirgoviste C, Widmer B, Dunger DB, Savage DA, Walker NM, Clayton DG, Todd JA: A genome-wide association study of nonsynonymous SNPs identifies a type 1 diabetes locus in the interferon-induced helicase (IFIH1) region. Nat Genet 2006, 38:617-619.

184. Martinez A, Varade J, Lamas JR, Fernandez-Arquero M, Jover JA, de la Concha EG, Fernandez-Gutierrez B, Urcelay E: Association of the IFIH1-GCA-KCNH7 chromosomal region with rheumatoid arthritis. Ann Rheum Dis 2008, 67:137-138.

185. Martinez A, Santiago JL, Cenit MC, de Las Heras V, de la Calle H, FernandezArquero M, Arroyo R, de la Concha EG, Urcelay E: IFIH1-GCA-KCNH7 locus: influence on multiple sclerosis risk. Eur J Hum Genet 2008, 16:861-864.

186. Sutherland A, Davies J, Owen CJ, Vaikkakara S, Walker C, Cheetham TD, James RA, Perros P, Donaldson PT, Cordell HJ, Quinton R, Pearce SH: Genomic polymorphism at the interferon-induced helicase (IFIH1) locus contributes 
to Graves' disease susceptibility. J Clin Endocrinol Metab 2007, 92:3338-3341.

187. Shigemoto T, Kageyama M, Hirai R, Zheng J, Yoneyama M, Fujita T: Identification of loss of function mutations in human genes encoding RIG-I and MDA5: implications for resistance to type I diabetes. J Biol Chem 2009, 284:13348-13354.

188. Miceli-Richard C, Gestermann N, Ittah M, Comets E, Loiseau P, Puechal X, Hachulla E, Gottenberg JE, Lebon P, Becquemont L, Mariette X: The CGGGG insertion/deletion polymorphism of the IRF5 promoter is a strong risk factor for primary Sjogren's syndrome. Arthritis Rheum 2009, 60:1991-1997.

189. Orozco G, Alizadeh BZ, Delgado-Vega AM, Gonzalez-Gay MA, Balsa A, PascualSalcedo D, Fernandez-Gutierrez B, Gonzalez-Escribano MF, Petersson IF, van Riel PL, Barrera P, Coenen MJ, Radstake TR, van Leeuwen MA, Wijmenga C, Koeleman BP, Alarcon-Riquelme M, Martin J: Association of STAT4 with rheumatoid arthritis: a replication study in three European populations. Arthritis Rheum 2008, 58:1974-1980.

190. Zervou MI, Goulielmos GN, Castro-Giner F, Tosca AD, Krueger-Krasagakis S: STAT4 gene polymorphism is associated with psoriasis in the genetically homogeneous population of Crete, Greece. Hum Immunol 2009, 70:738-741

191. Boone DL, Turer EE, Lee EG, Ahmad RC, Wheeler MT, Tsui C, Hurley P, Chien M, Chai S, Hitotsumatsu O, McNally E, Pickart C, Ma A: The ubiquitin-modifying enzyme $\mathrm{A} 20$ is required for termination of Toll-like receptor responses. Nat Immunol 2004, 5:1052-1060.

192. Feng XB, Shen N, Qian J, Sun L, Hua J, Chen SL: Single nucleotide polymorphisms of deoxyribonuclease I and their expression in Chinese systemic lupus erythematosus patients. Chin Med J (Engl) 2004, 117:1670-1676.

193. Dittmar M, Bischofs C, Matheis N, Poppe R, Kahaly GJ: A novel mutation in the DNASE1 gene is related with protein instability and decreased enzyme activity in thyroid autoimmunity. J Autoimmun 2009, 32:7-13.

194. Bodano A, Gonzalez A, Ferreiros-Vidal I, Balada E, Ordi J, Carreira P, GomezReino JJ, Conde C: Association of a non-synonymous single-nucleotide polymorphism of DNASEl with SLE susceptibility. Rheumatology (Oxford) 2006, 45:819-823

195. Yokoi N, Fujiwara Y, Wang HY, Kitao M, Hayashi C, Someya T, Kanamori M, Oiso Y, Tajima N, Yamada Y, Seino Y, Ikegami H, Seino S: Identification and functional analysis of CBLB mutations in type 1 diabetes. Biochem Biophys Res Commun 2008, 368:37-42.

196. Donn RP, Barrett JH, Farhan A, Stopford A, Pepper L, Shelley E, Davies N, Ollier WE, Thomson W: Cytokine gene polymorphisms and susceptibility to juvenile idiopathic arthritis. British Paediatric Rheumatology Study Group. Arthritis Rheum 2001, 44:802-810.

197. Morrison VA, Onengut-Gumuscu S, Concannon P: A functional variant of IRS1 is associated with type 1 diabetes in families from the US and UK. Mol Genet Metab 2004, 81:291-294.

198. De Jager PL, Franchimont D, Waliszewska A, Bitton A, Cohen A, Langelier D, Belaiche J, Vermeire S, Farwell L, Goris A, Libioulle C, Jani N, Dassopoulos T,
Bromfield GP, Dubois B, Cho JH, Brant SR, Duerr RH, Yang H, Rotter Jl, Silverberg MS, Steinhart AH, Daly MJ, Podolsky DK, Louis E, Hafler DA, Rioux JD: The role of the Toll receptor pathway in susceptibility to inflammatory bowel diseases. Genes Immun 2007, 8:387-397.

199. Castiblanco J, Varela DC, Castano-Rodriguez N, Rojas-Villarraga A, Hincapie ME, Anaya JM: TIRAP (MAL) S180L polymorphism is a common protective factor against developing tuberculosis and systemic lupus erythematosus. Infect Genet Evol 2008, 8:541-544.

200. Jacob CO, Zhu J, Armstrong DL, Yan M, Han J, Zhou XJ, Thomas JA, Reiff A, Myones BL, Ojwang JO, Kaufman KM, Klein-Gitelman M, McCurdy D, WagnerWeiner L, Silverman E, Ziegler J, Kelly JA, Merrill JT, Harley JB, RamseyGoldman R, Vila LM, Bae SC, Vyse TJ, Gilkeson GS, Gaffney PM, Moser KL, Langefeld CD, Zidovetzki R, Mohan C: Identification of IRAK1 as a risk gene with critical role in the pathogenesis of systemic lupus erythematosus. Proc Natl Acad Sci U S A 2009, 106:6256-6261.

201. Radstake TR, Franke B, Hanssen S, Netea MG, Welsing P, Barrera P, Joosten LA, van Riel PL, van den Berg WB: The Toll-like receptor 4 Asp299Gly functional variant is associated with decreased rheumatoid arthritis disease susceptibility but does not influence disease severity and/or outcome. Arthritis Rheum 2004, 50:999-1001.

202. Palomino-Morales R, Torres O, Vazquez-Rodriguez TR, Morado IC, Castaneda S, Callejas-Rubio JL, Miranda-Filloy JA, Fernandez-Gutierrez B, Martin J, Gonzalez-Gay MA: Association between toll-like receptor 4 gene polymorphism and biopsy-proven giant cell arteritis. J Rheumatol 2009, 36:1501-1506.

203. Hirankarn N, Tangwattanachuleeporn M, Wongpiyabovorn J, Wongchinsri J, Avihingsanon Y: Genetic association of interferon-alpha subtypes 1, 2 and 5 in systemic lupus erythematosus. Tissue Antigens 2008, 72:588-592.

204. Miterski B, Jaeckel S, Epplen JT, Pohlau D, Hardt C: The interferon gene cluster: a candidate region for MS predisposition? Multiple Sclerosis Study Group. Genes Immun 1999, 1:37-44.

205. Leyva L, Fernandez O, Fedetz M, Blanco E, Fernandez VE, Oliver B, Leon A, Pinto-Medel MJ, Mayorga C, Guerrero M, Luque G, Alcina A, Matesanz F: IFNAR1 and IFNAR2 polymorphisms confer susceptibility to multiple sclerosis but not to interferon-beta treatment response. J Neuroimmunol 2005, 163:165-171.

206. Tao K, Fujii M, Tsukumo S, Maekawa Y, Kishihara K, Kimoto Y, Horiuchi T, Hisaeda H, Akira S, Kagami S, Yasutomo K: Genetic variations of Toll-like receptor 9 predispose to systemic lupus erythematosus in Japanese population. Ann Rheum Dis 2007, 66:905-909.

doi:10.1186/ar2883

Cite this article as: Delgado-Vega AM, et al: Genetic associations in type interferon related pathways with autoimmunity. Arthritis Research \& Therapy 2010, 12(Suppl 1):S2 